\title{
بحث بعنوان'
}

إطار مقترح للمراجعة الضريبية وإنعكاس ذلك على جودة التقارير المالية

$$
\text { والإقرارات الضريبية }
$$

\author{
أحمد كمال الطيار \\ مدرس مساعد
}

كلية التجارة-جامعة القاهرة

\author{
د/ هشام محمد الحموي \\ مدرس المحاسبة
}

كلية التجارة-جامعة القاهرة
أ. أد منصور حامد محمود

استاذ المحاسبة الخاصة

كلية التجارة-جامعة القاهرة

\section{$p^{r+19-\$ 1} \mid \leq \varepsilon$.}

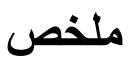

يهدف هذا البحث إلى وضع إطار مقترح بساعد في تحسين جودة الأداء المهني للمراجع الضريبي الخارجي وإنعكاس ذللك على جودة التقارير المالية والإقرارات الضريبية، وقد قسمت مقومات هذا الإطار إلى ثلاث مجموعات: تمثلت في دقات مقومات خاصة بالمراجع الضريبي، مقومات خاصة بالبيئة الخارجية، مقومات خاصة بلات بالعميل

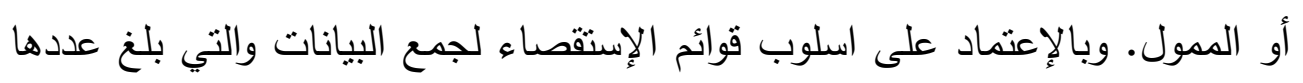

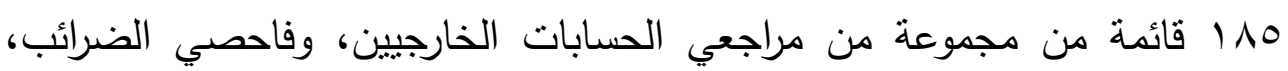

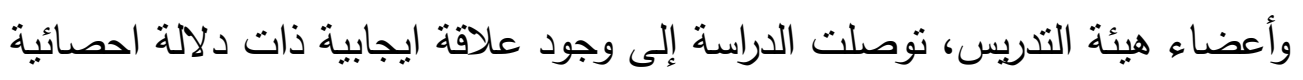

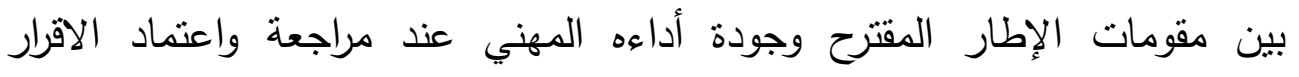
الضريبي، كما توصل إلى وجود علاقة ايجابية ذات دلالة إحصائية بين تحسين جودة الأداء المهني للمراجع الضريبي الخارجي وجودة التقارير المالية والإقرارات الضربيية. كلمـات الفهرسـة: الحوكمـة الضـريبية- المراجعـة الضـريبية- جودة الأداء المهني للمراجع الضريبي - جودة التقارير المالية.

1. هذا البحث استكمالاً لمتطبات مناقثة رسالة دكتور الفلسفة في المحاسبة بعنوان "دراسة تحليلية للعوامل فئل

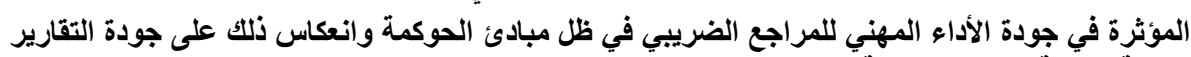
المالية"، كلية التجارة، جامعة القاهرة. 


\section{طبيعة المشكلة}

تعد الضرائب أحد أهم الأدوات الاقتصادية والمالية للدولة، والتي تستطيع من

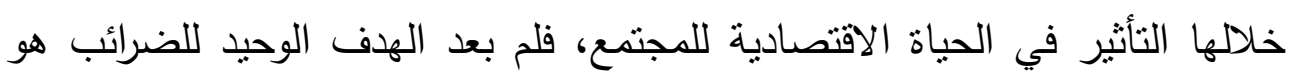

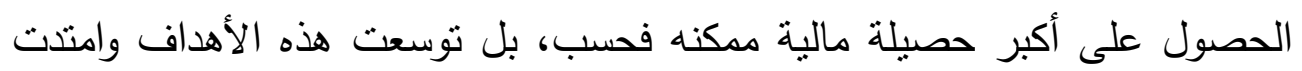
لتتجيع عملية التتمية الإقتصادية والإجتماعية وتحقيق التوازن على المستوى المحلي مليكي

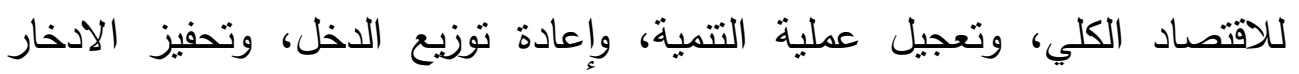

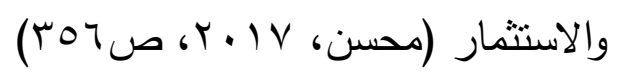

الأمر الذي جعلها تتال اكبر قدر من الاهتمام نحو وضع تشريع ضريبي يصاغ

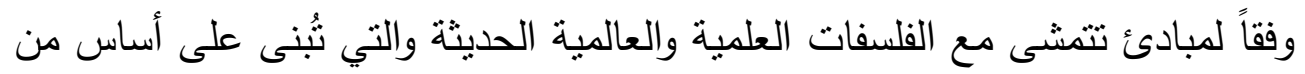

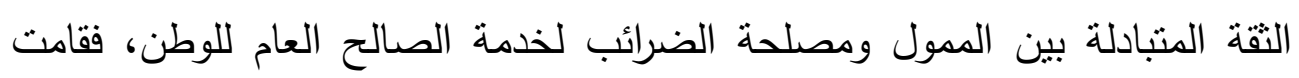

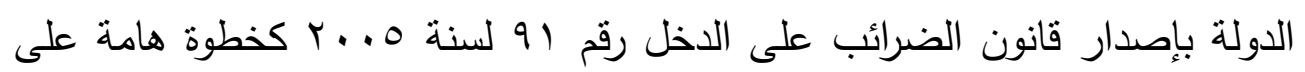

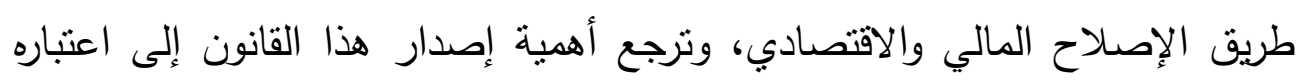

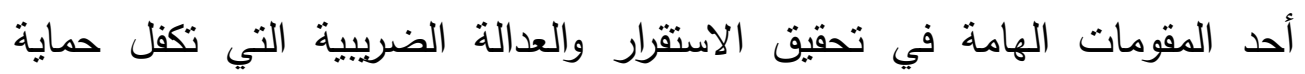
المجتمع، علاوة على ضمان نتجيع وجذب الاستثمار المحلي والاجنبي (الناغي،

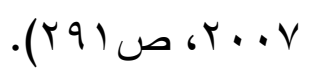

ومع صدور قانون الضرائب الجديد أصبح المراجع الخارجي يلعب دوراً هاماً

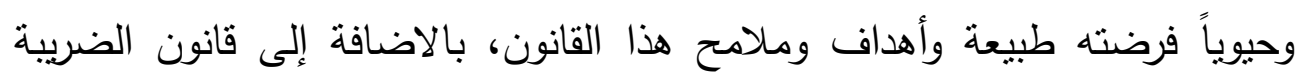

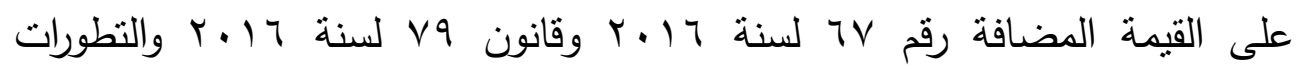

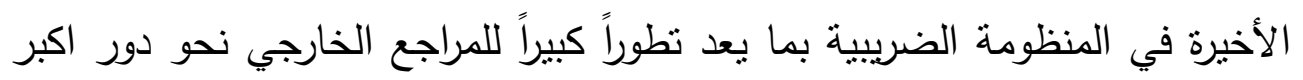
وأساسي ومؤثر في العديد من المجالات لعل من أهمها الاعتماد على التقارير والقوائم

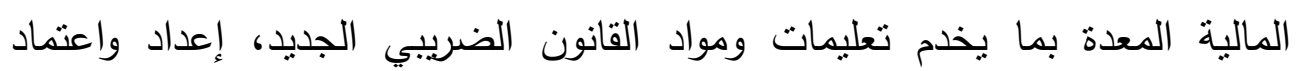

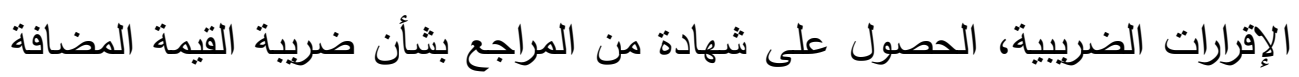

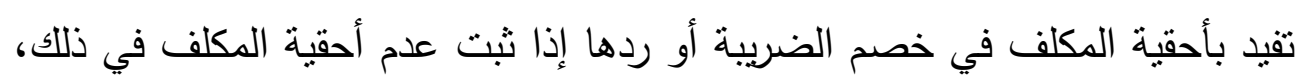

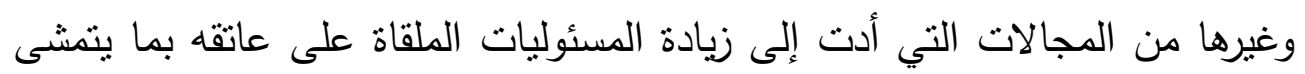
مع هذا الدور الفعال. - من التجات 
هذا، ويتضمن دور المراجع في المجال الضريبي كافة الأعمال التي يقوم بها

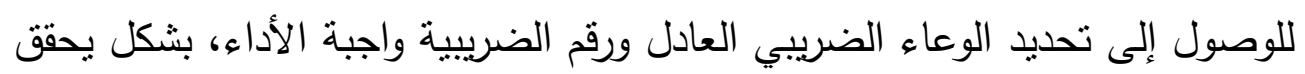

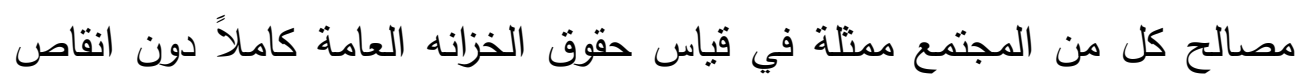

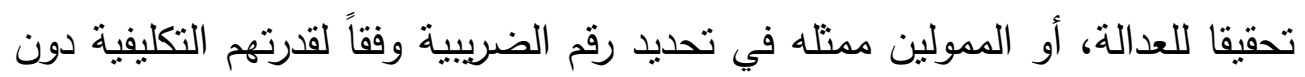

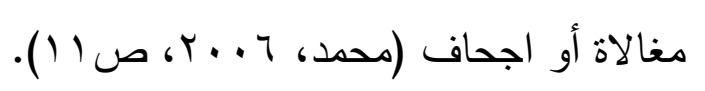

وقد إختلفت الدراسات السابقة فيما بينها فى تحديد العوامل المؤثرة فى جودة الاداء

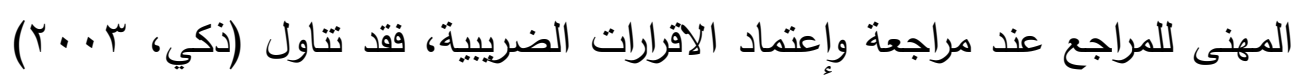

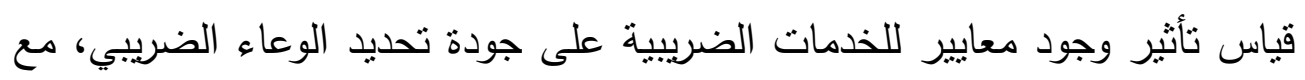

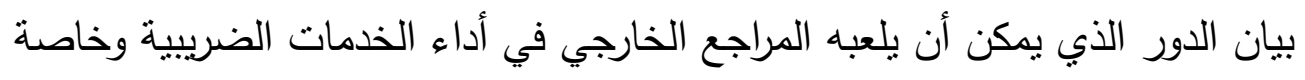

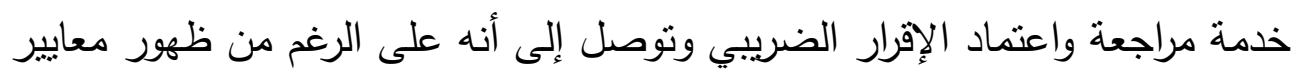

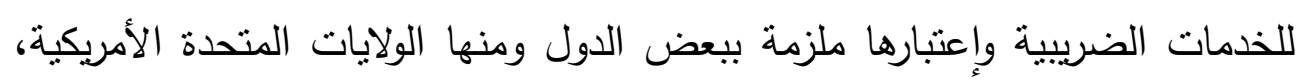
فما زالت غائبة عن التطبيق في مصر. كما تتاول (Dezoort, 2012) مسئولية

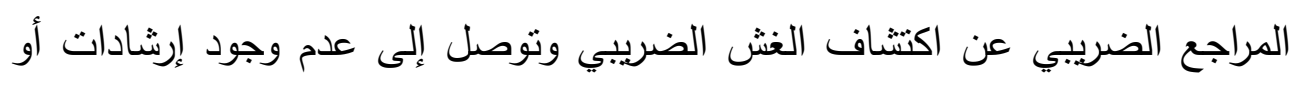

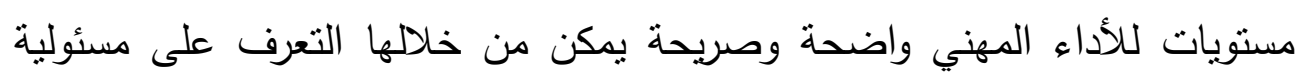

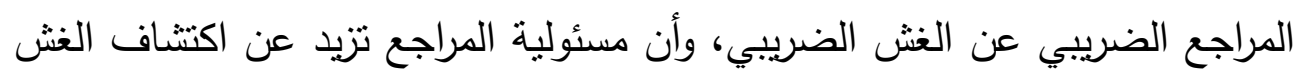

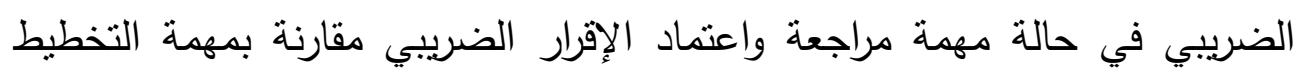

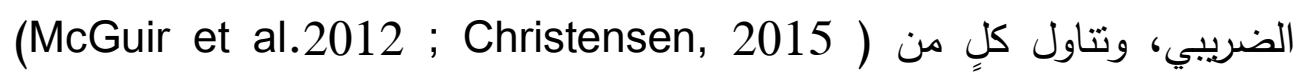
العلاقة بين الخبرة الضريبية بالقوانين والنتريعات الضريبية للمراجع وتطويع الأرباح

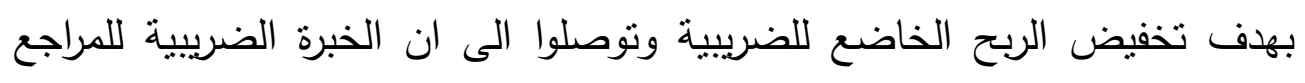

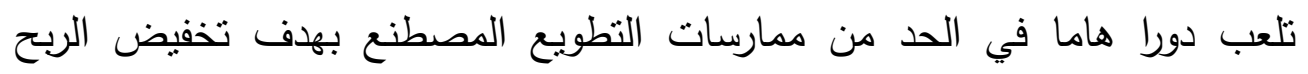

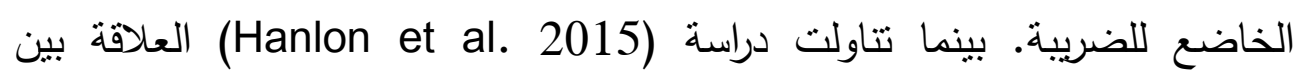
الفحص الضريبي من قبل السلطات الضريبية جودة التقارير المالية، وأثارت الدراسة

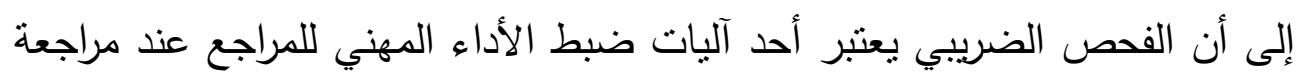

$$
\text { واعتماد الاقرارات الضريبية. }
$$

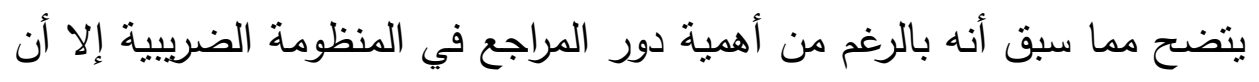

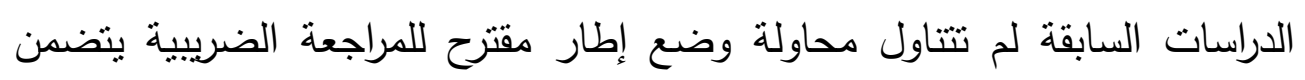


مجموعة من المقومات التي تعمل على تدعيم الدور الرقابي للمراجع عند قيامه بمهام

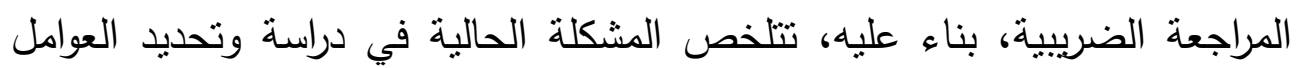
المؤثرة على جودة الأداء المهني للمراجع عند قيامه بمهام مراجعة واعتماد الإقرار

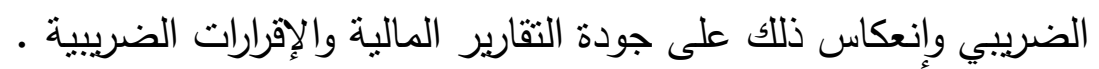

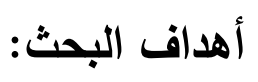

يتمنل الهدف الرئيس للبحث في تحسين جودة المراجعة الضريبية الخارجية من

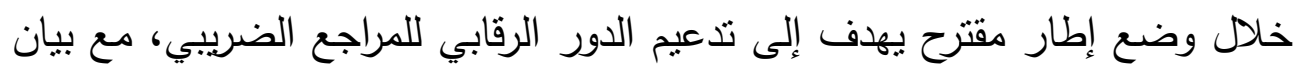

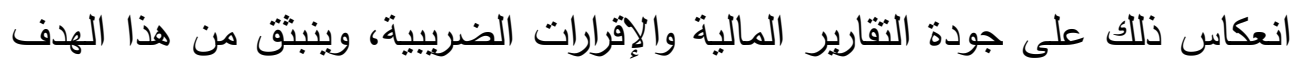
مجموعة أهداف فرعية تتمتل فيما يلي: لئي - تدعيم مفهوم المراجعة الضريبية الخارجية بالبيئة الدصرية. - تحديد مقومات الإطار المقترح لتحسين جودة المراجعة الضريبية الخارجية.

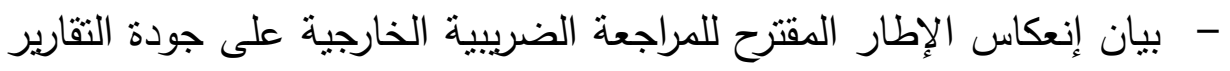

$$
\text { المالية والإقرارات الضريبية. }
$$

فروض البحث:

بناءاً على الأهداف التي يسعى البحث إلى تحقيقها، فإن فروض البحث يمكن

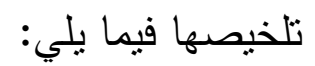

الفرض الأول: توجد علاقة ايجابية بين مقومات الإطار المقترح للمراجعة

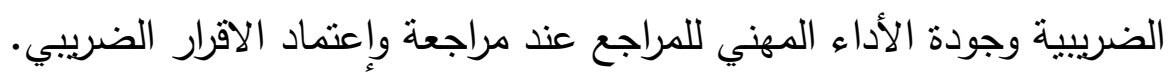
الفرض الثاني: توجد علاقة ايجابية بين مقومات الإطار المقترح وجودة التقارير المالية والإقرارات الضريبية.

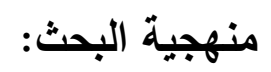
يثير مصطلح منهج البحث (Research Methodology) إلى المنهجية العامة والفلسفة التي يتبعها الباحث للإجابة على التساؤلات البحثية، واختبار الفروض.

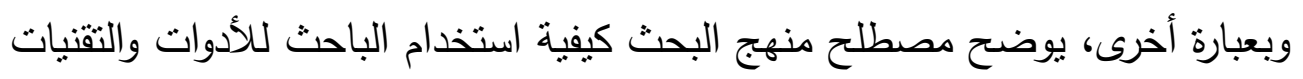

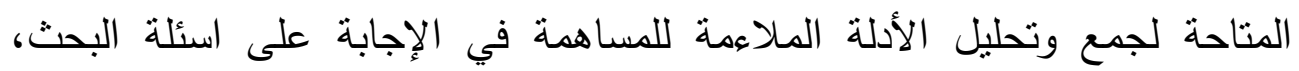

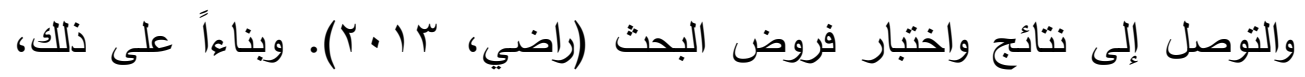


أعتمد الباحث على المنهج الإسنقرائي، حيث يتم الإستدلال المنطقي من خلال

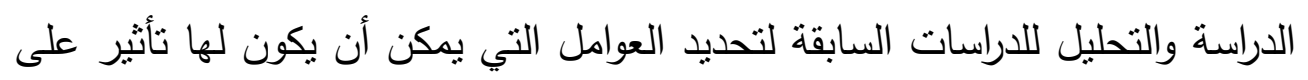

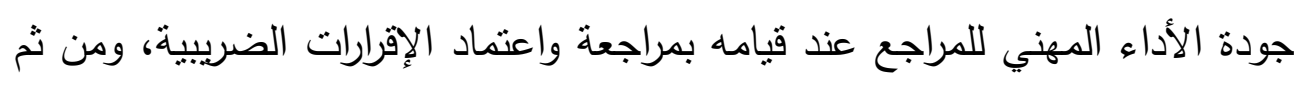

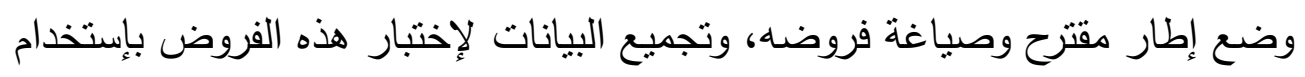

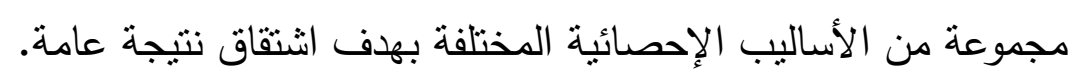
خطة البحث: مجثرعة من

يشتمل البحث في الأجزاء التالية على عدة نقاط تتمنل في دور المراجع في ظل الفال

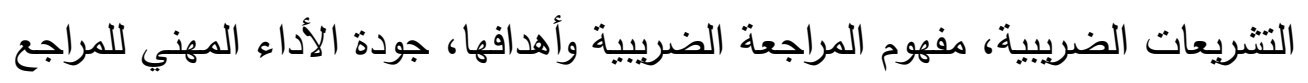

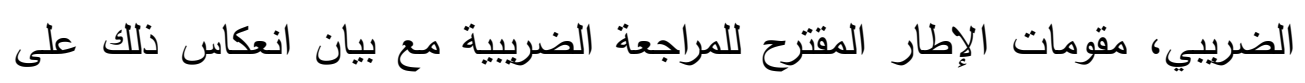

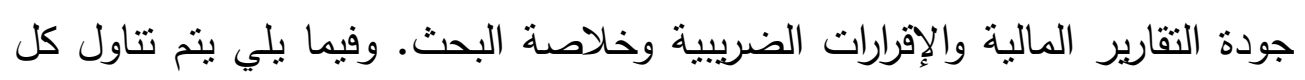
جزء من الأجزاء السابقة حسب ترتيبها: 1- دور المراجع الخارجي في ظل التشريعات الضريبية:

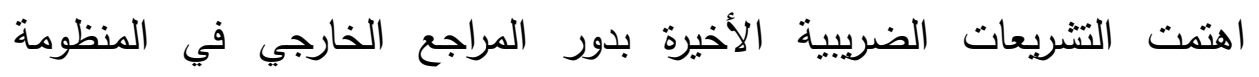

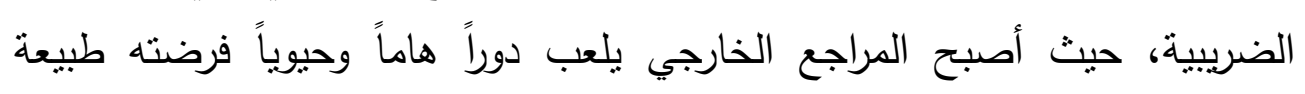

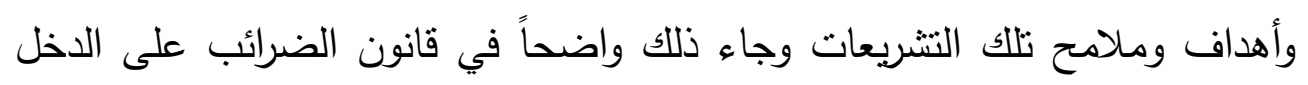

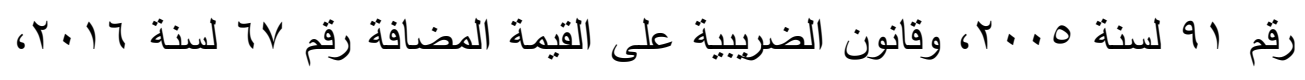

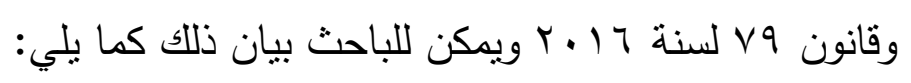

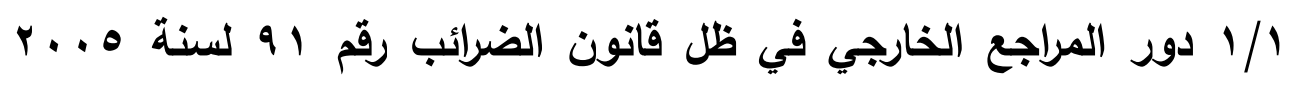
وتعديلاته:

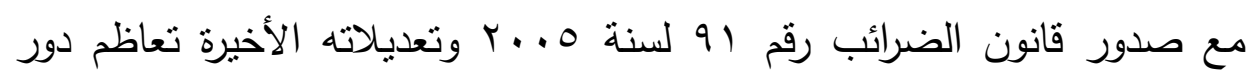

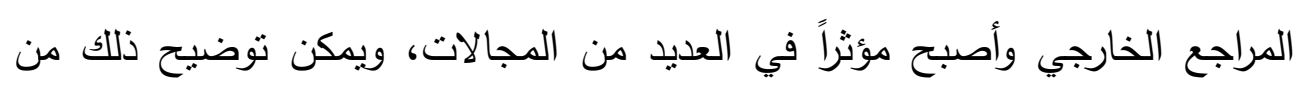

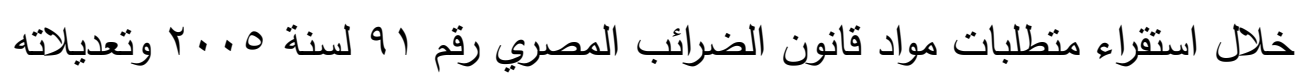
كما يلي:

الاعتماد على التقارير والقوائم المالية المعدة بما يخدم تعليمات ومواد القانون

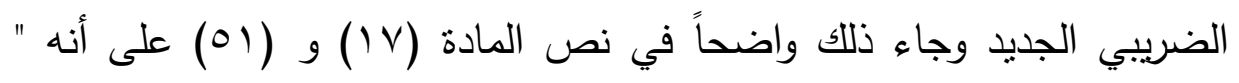

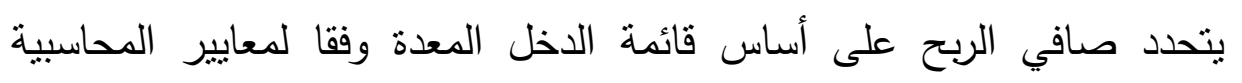


المصرية، كما يتحدد وعاء الضريبة بتطبيق أحكام هذا القانون على صافي الربح

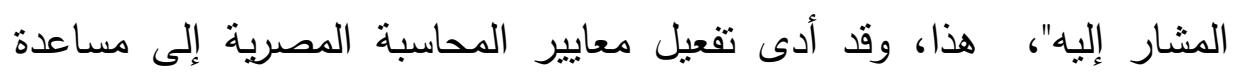

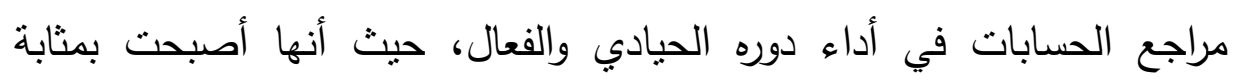

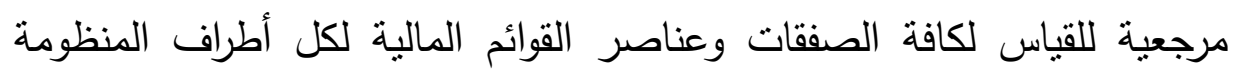

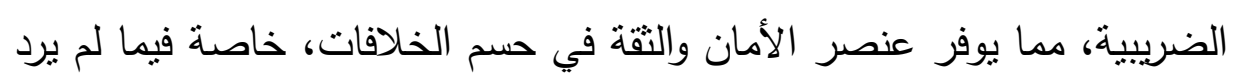
به نص واضح وصحيح بالتشريع الضريبي (نجم، ـ ا • ب).

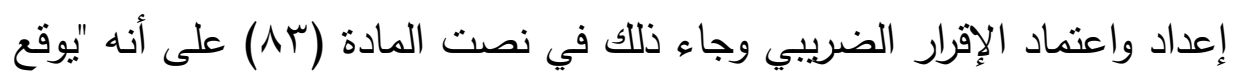

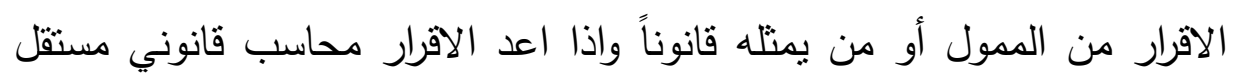

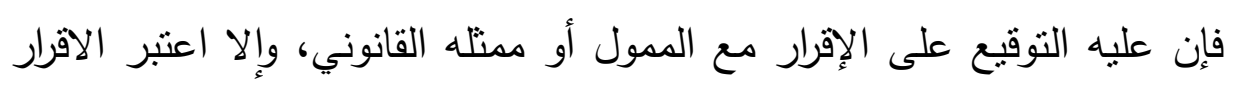

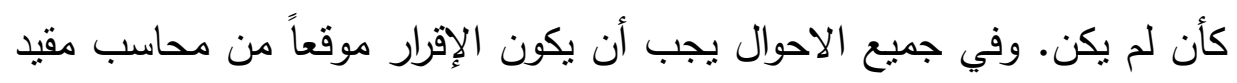

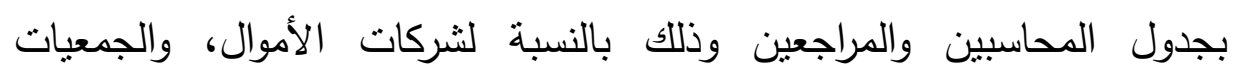
التعاونية، والأشخاص الطبيعين، وشركات الاشخاص إذا تجاوز رقم الأعمال لأي

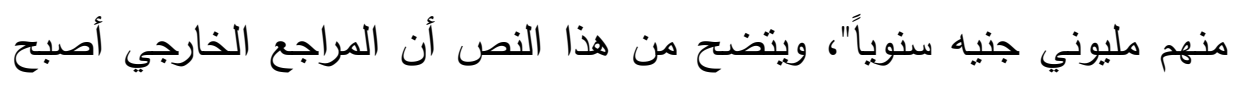

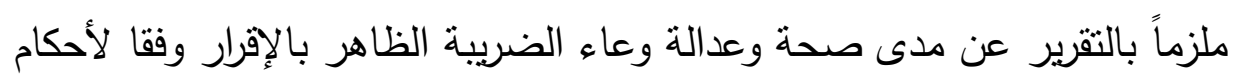

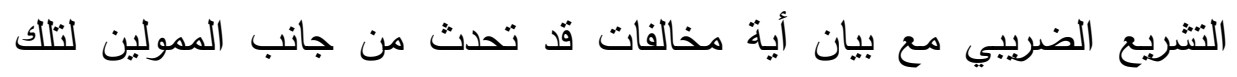

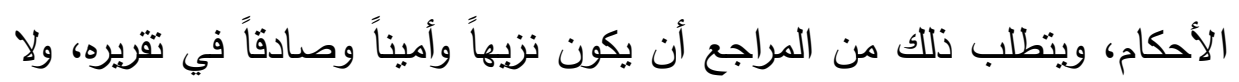

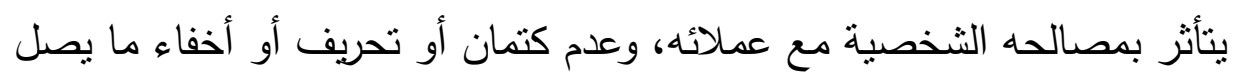

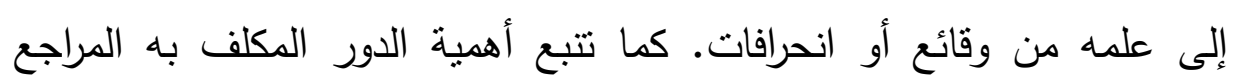

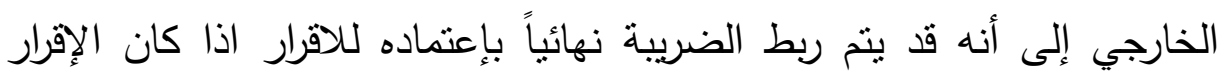

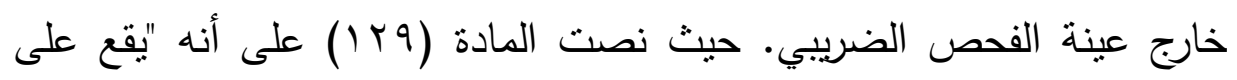

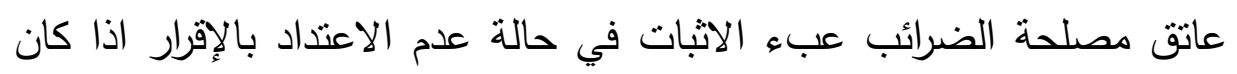

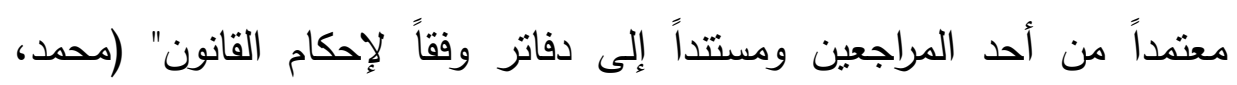
. (Y. T تقديم تقرير بشأن الديون المعدومة التي قام الممول بإستبعادها من دفاتر الثركة

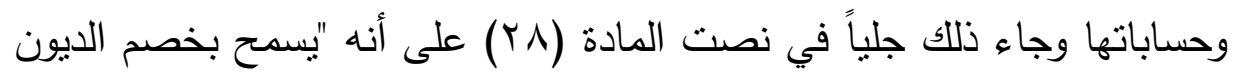

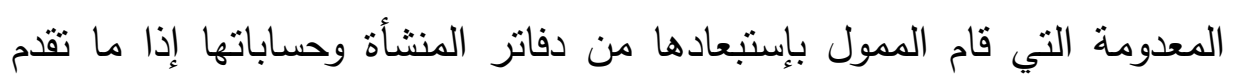


بتقرير من أحد المحاسبين المقيدين بجدول المحاسبين والمراجعين يفيد نوافر

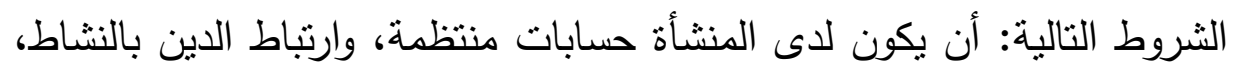

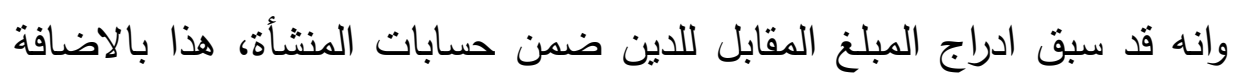

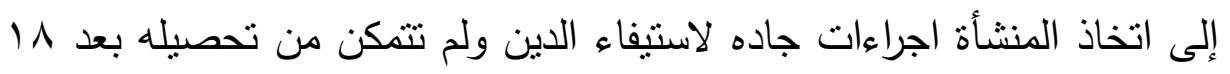

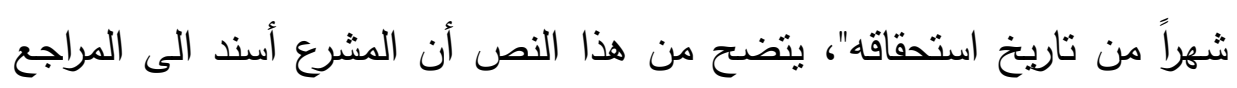

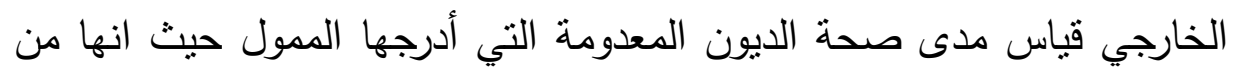
البنود التي لها تأثثر سالب على وعاء هاء الضريبة.

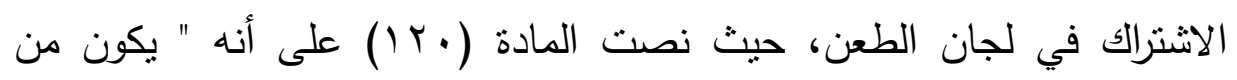

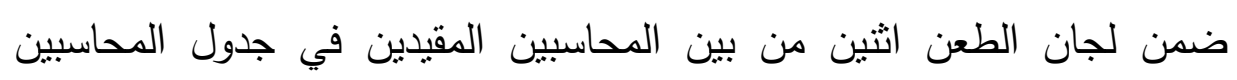

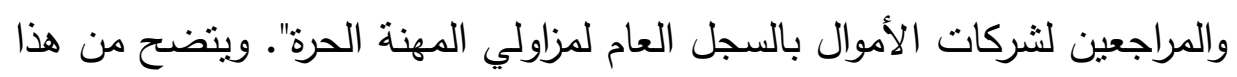

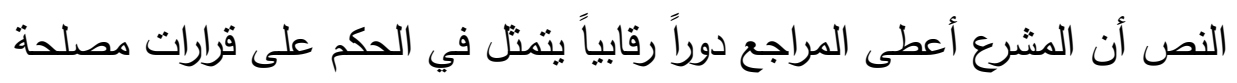

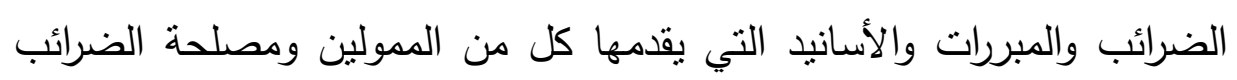

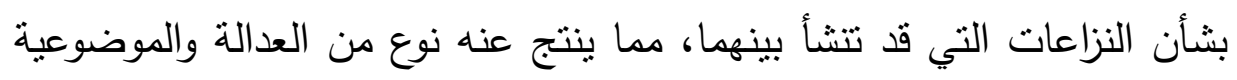

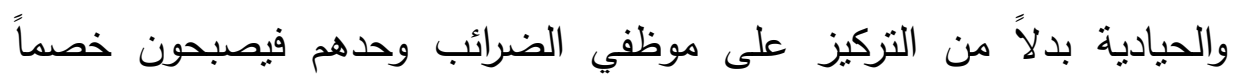
وحكماً في نفس الوقت. الاثتراك في مكافحة جريمة التهرب حيث جعل المشرع المراجع مسئولاً بالتضامن

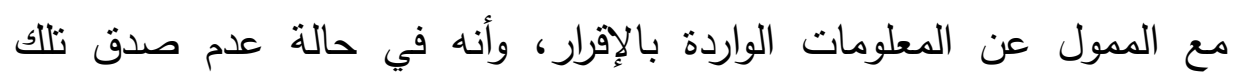

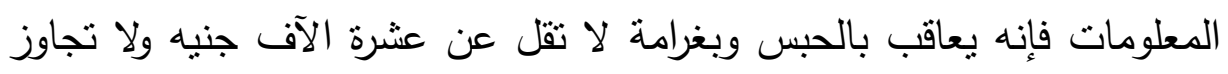

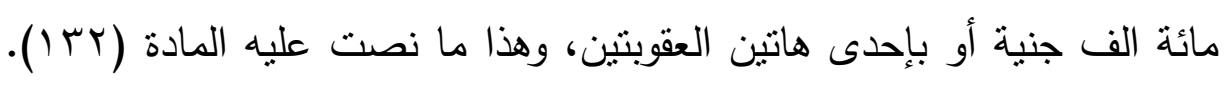

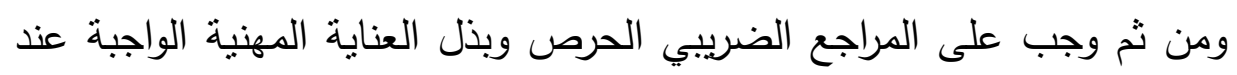
مراجعة واعتماد الإقرار الضريبي حتى ينأى بنفسه عن أب شبها لفه قد تعرضيه للمسئولية القانونية. الاثتراك في المجلس الأعلى للضرائب من خلال نص المادة (9 ب ( ) من قانون

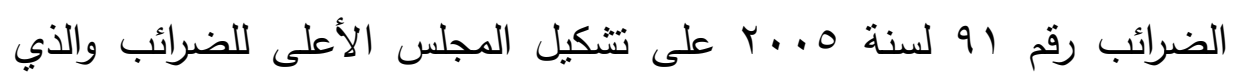

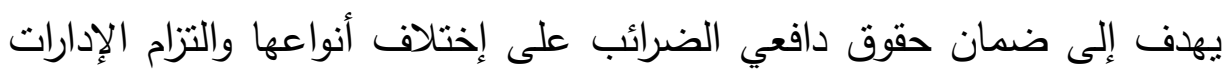

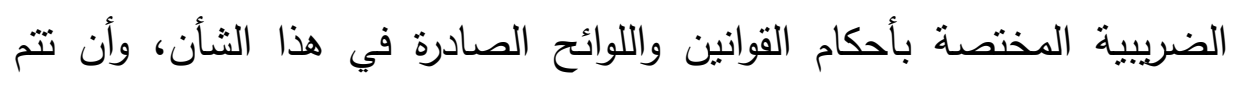


إجراءات الربط والتحصيل في إطار من التعاون وحسن النية، وكذلك توجيه

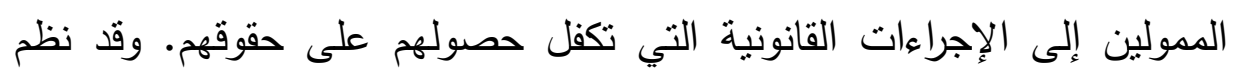
المشرع اختصاصات واجتماعات وموارد ذلك المجلس واختيار اعضائه لتحقيق التشيق

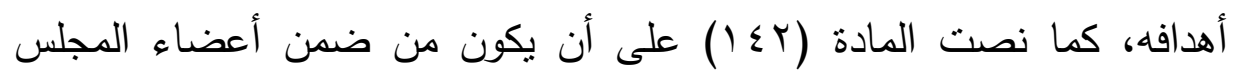

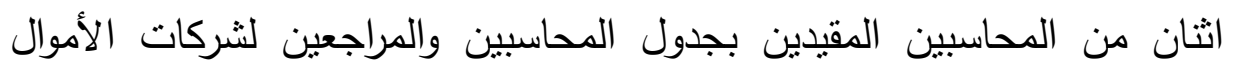

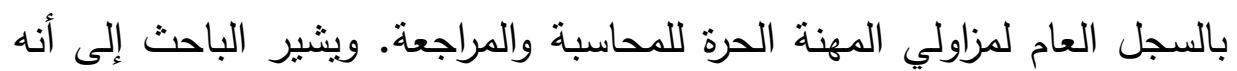
حتى الآن لم يتم اتخاذ اجراءات جادة لتفعيل دور هذا المجلس.

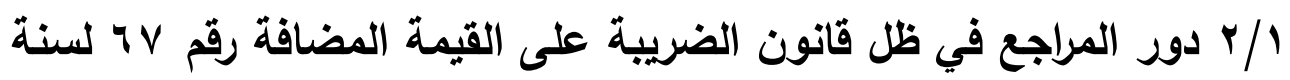
$: Y \cdot 19$ نصت المادة (·r) من قانون ضريبة القيمة المضافة على "ضرورة حصول

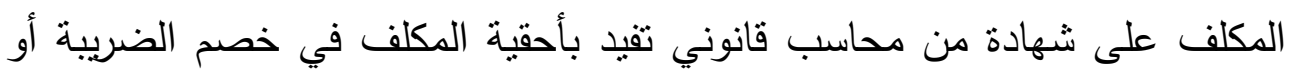

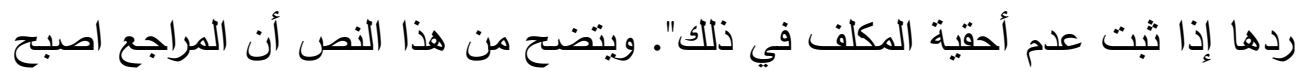

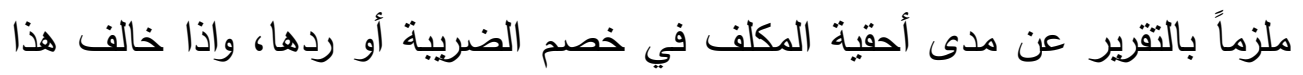

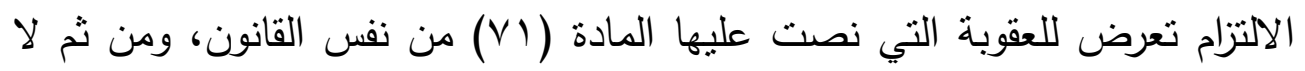

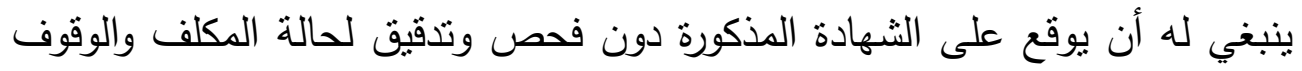
على مدى أحقيته فيما يطالب به به بله

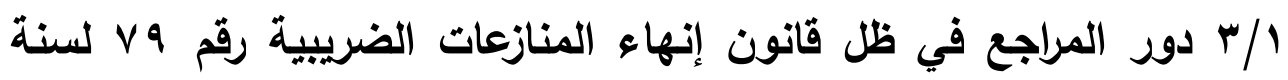
$: Y \cdot 19$

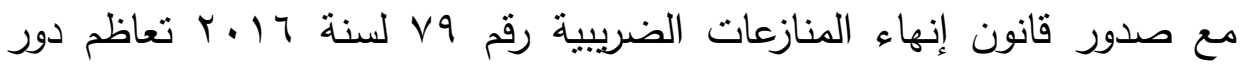

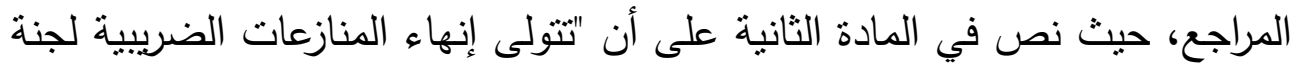

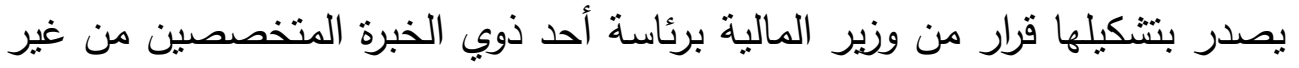

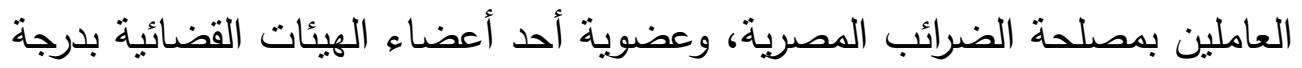

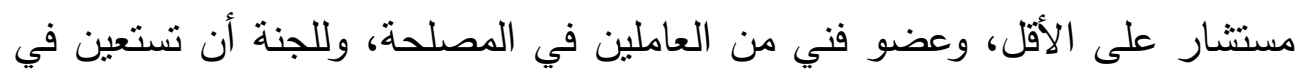

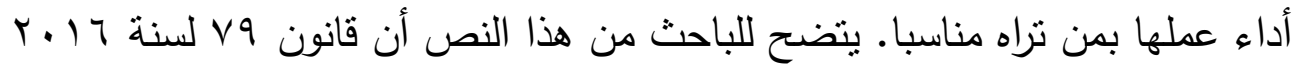
قد عظم من دور المراجع في المنظومة الضريبية وجعله رئيساً لهذه اللجنة المستقلة لئل 
والتي تقوم بالفصل في المنازعات الضريبية التي قد تنشأ بين الممول ومصلحة الضرائب.

\section{r / مفهوم المراجعة الضريبية.}

جاء التشريعات الضريبية الأخيرة بفكر جديد مفاده إعادة الثقة والتواصل بين الإدارة الضريبية والممولين من خال إيجاد دور فعال لمراجع الحسابات في إنجاح

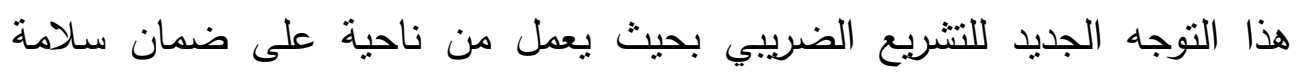

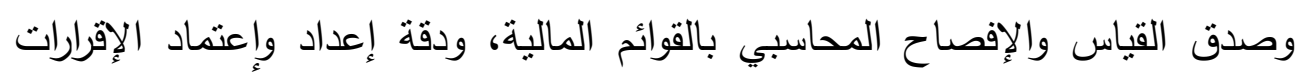
الضريبية، الأمر الذي جعل من المراجع الخارجي بصفة عامة والمالئ المراجع الضريبي

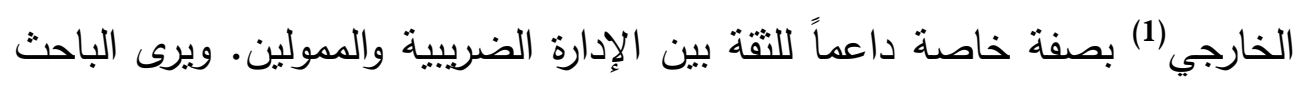

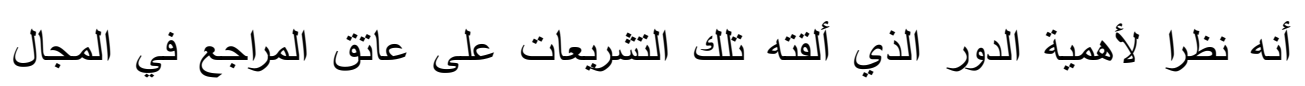

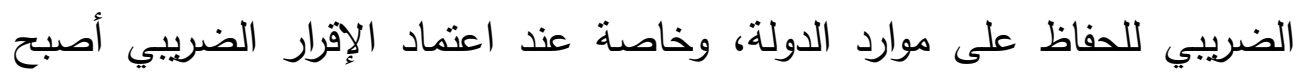

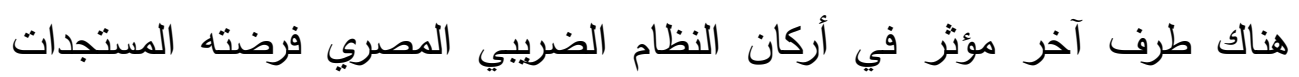

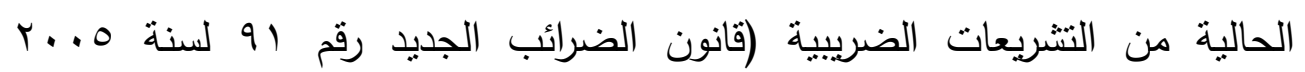

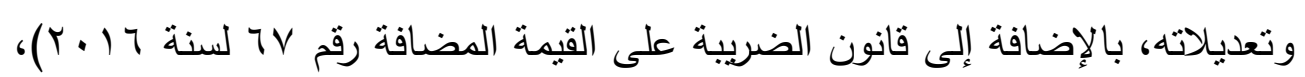

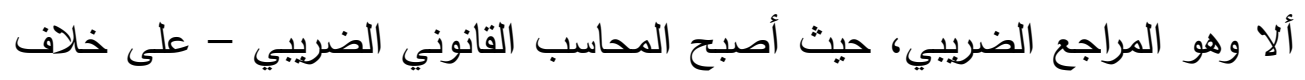

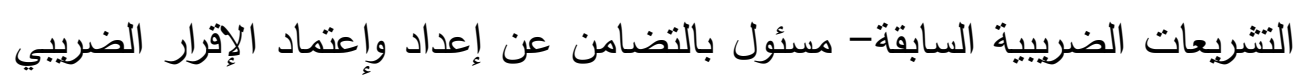

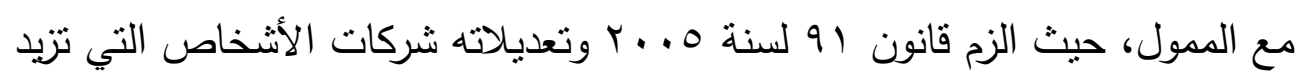

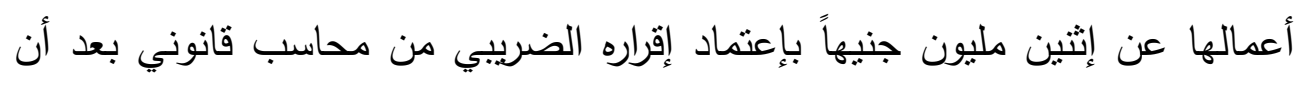

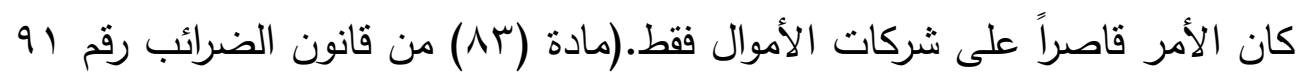

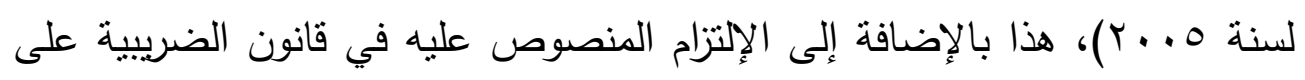

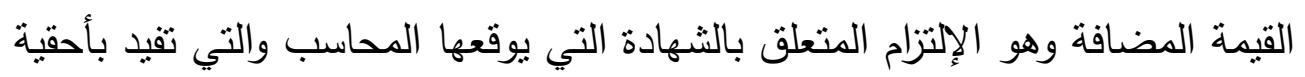

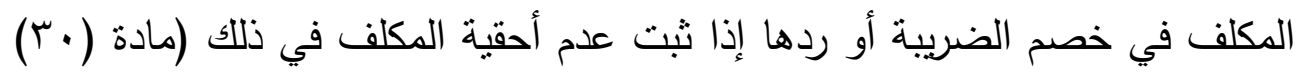

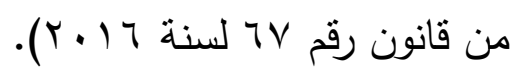

(1) يقصد بالمراجع الضريبي الخارجي: المحاسب القانوني الذي يقوم بمراجعة وإعتماد الإقرار الضريبي للممول، وسيقوم الباحث بإستخدام هذا المصطتح في باقي أجزاء البحثث. 
ولإبراز ماهية المراجع المالي والمراجع الضريبي وطبيعة عمليهما يتعين أن يكون ذلك من خلال معرفة هدف المراجعة المالية وهدف المراجعة الضريبية ومدى إمكانية الجمع بين هاتين المراجتين تحت إثراف مكتب محاسب قانوني واحد لأداء خدمة المراجعة المالية والضريبية معاً. فإذا كان هدف المراجعـة الماليـة هو إبداء رأي فني محايد عن مدى دلايلـة القوائم

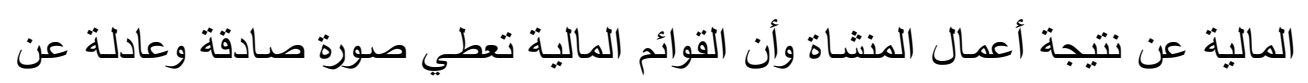
حقيقة المركز المالي. فإن هدف المراجعة الضريبية هو التأكيد على صحة وعدالة بيانات الإقرارات الضريبية

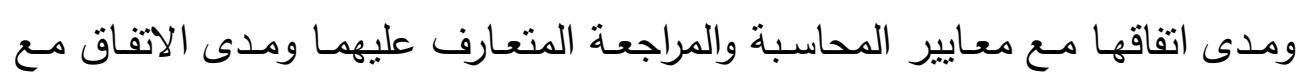
القوانين الضريبية السارية وتعليمات مصلحة الضرائب المصرية.

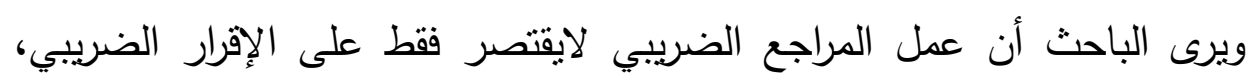

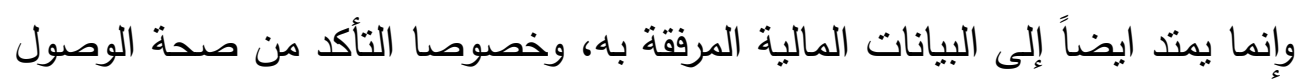

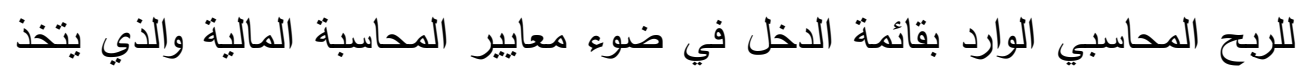

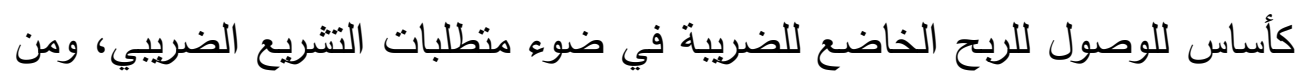

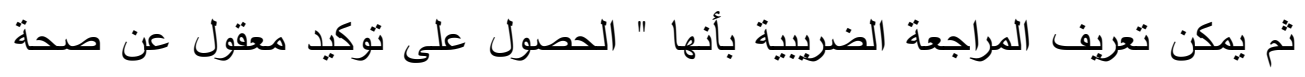

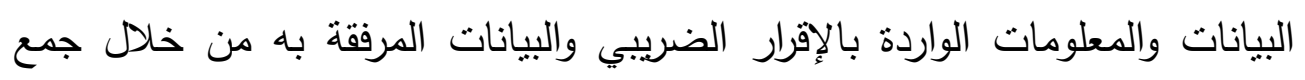

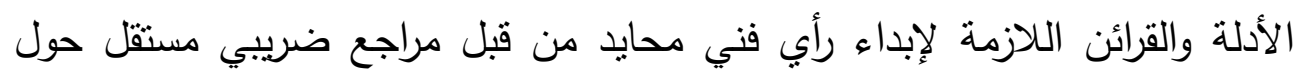

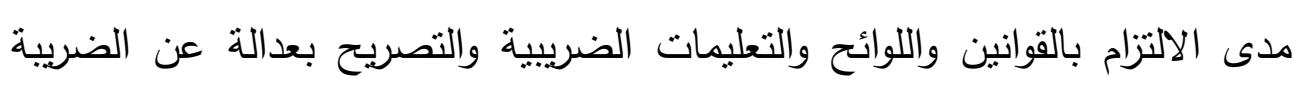

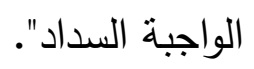

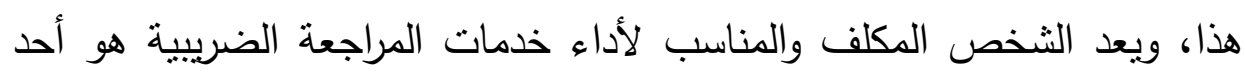

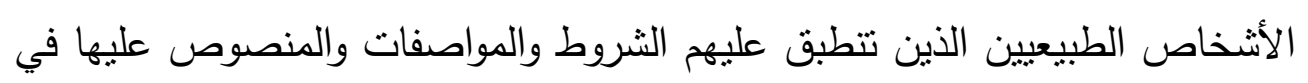
قانون مزاولة مهنة المحاسبة والمراجعة. وتتمثل هذه الثروط في نوافر الثرو الخبرة الكافية

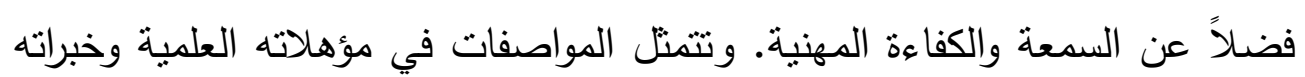
وكفاءته، وأن تكون قدراته متتاسبة مع حجم وطبيعة نشاط الثركة. ويرى الباحث هناك ضرورة لبحث سبل دعم استقلال المراجع الضريبي سوء من خلال الفصل بينه ونئه

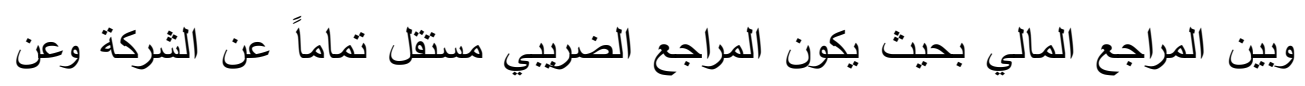


أعضاء مجلس إدارتها. يعين بقرار من الجمعية العامة بناء على ترشيح من لجنة

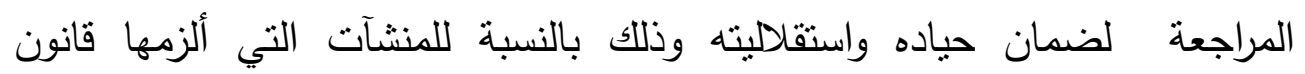
الثركات بتعيين مراجع حسابات خارجي، أو وضع آليات تعمل على دعم استقاد

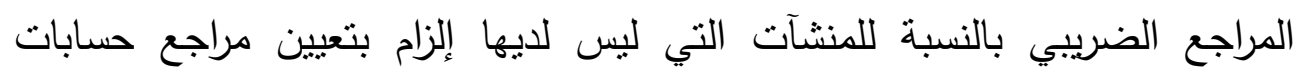
خارجي. r/ أهداف المراجعة الضريبية: يمكن للباحث بيان أهم أهداف المراجعة الضريبية فيما يلي:

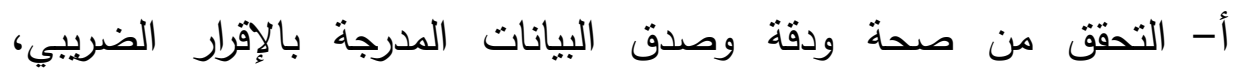

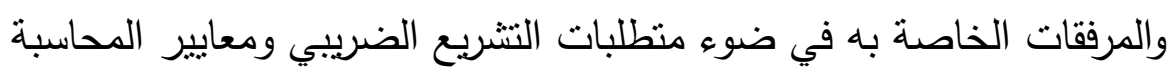

$$
\text { المصرية. }
$$

ب-توفير الثقة من قبل مصلحة الضرائب في صدق وعدالة البيانات الواردة بالإقرار الضريبي والوصول إلى الربح الخاضع للضريبة.

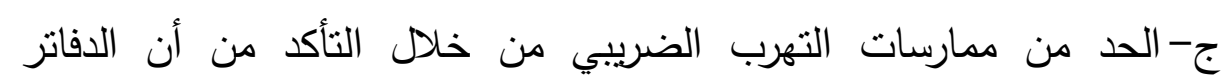

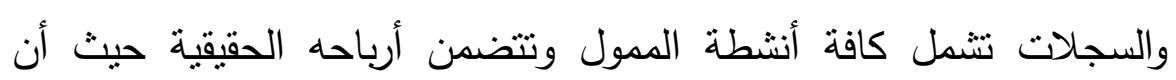

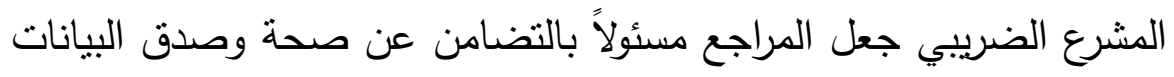
الواردة بالإقرار الضريبي مما يفرض على المراجع القيام ببذل العناية المهنية الواجبة عند مراجعة الإقرار حتى ينأى بنفسه عن التعرض للمسألة القانونية.

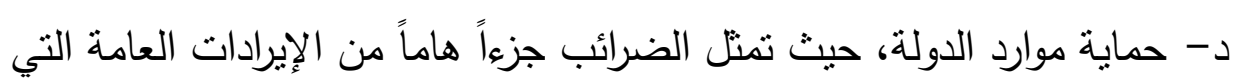

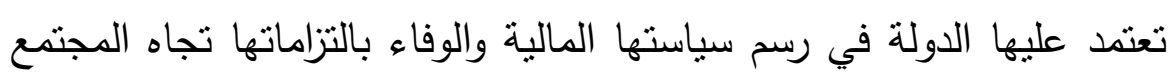

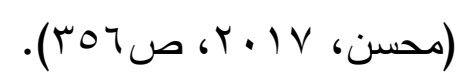

هـ-تخفيض عدد قضايا المنازعات الضريبية، وزيادة مستوى الإلتزام الطوعي لدى

الممولين.

\section{ب/r جودة الأداء المهني للمراجع الضريبي الخارجي:}

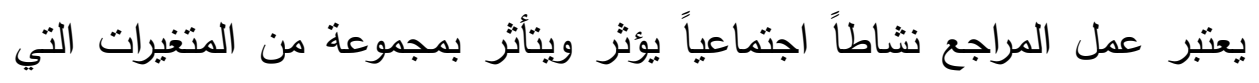

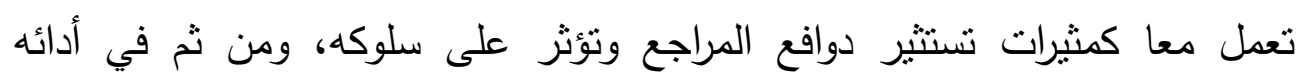

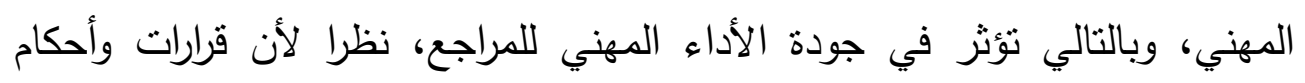


المراجع سوف يكون لها انعكاساتها ليس فقط على المنثأة محل المراجعة، بل تمتد

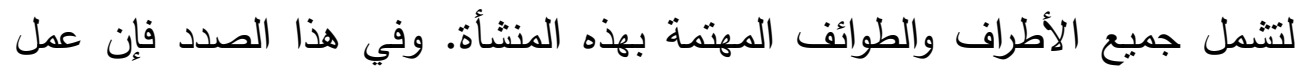

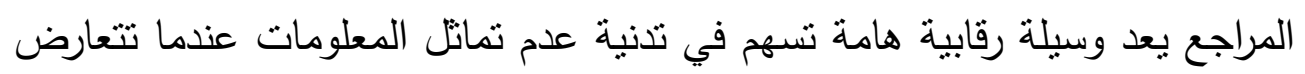
مصالح الأصيل مع مصالح الوكيل، من خلال نوفير تأكيد معقول أن القوائم المالية

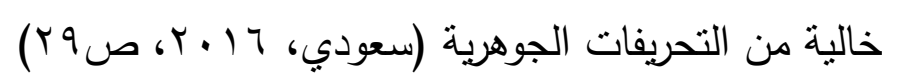

ويعتبر مفهوم جودة الأداء المهني للمراجع مفهوماً مركباً ذو أبعاد مختلفة حيث أنها

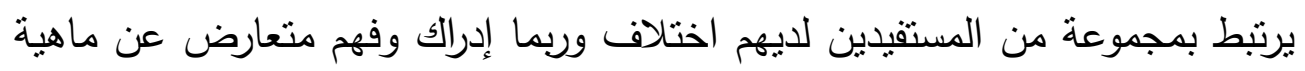

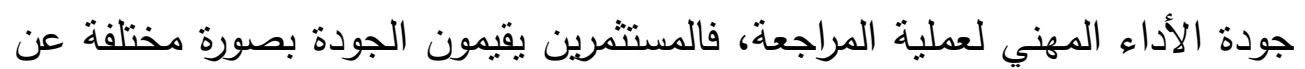
حملة الأسهم، وهؤلاء بدورهم يقيمونها بشكل مختلف عن مديري الشركات، وكل هؤلاء

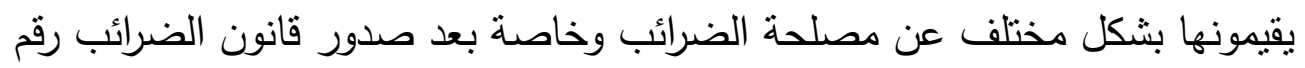

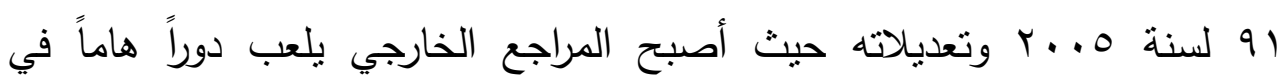

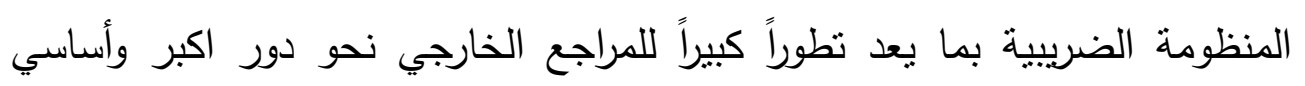

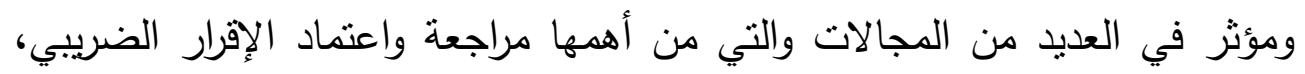

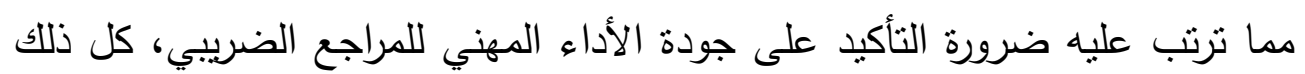
قد أدى إلى ثباين واختلاف وجهات النظر حول ذلك المفهوم

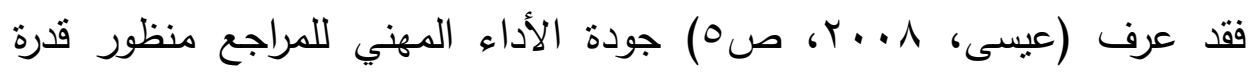

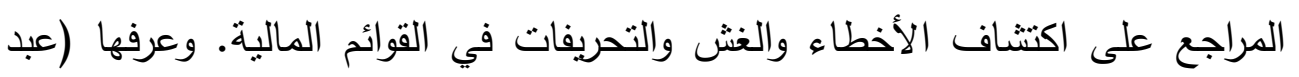

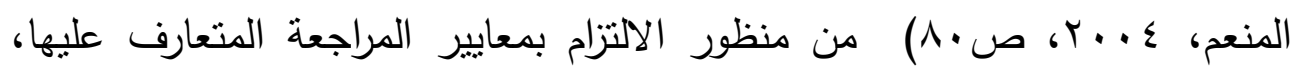

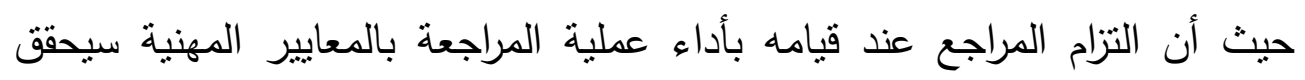

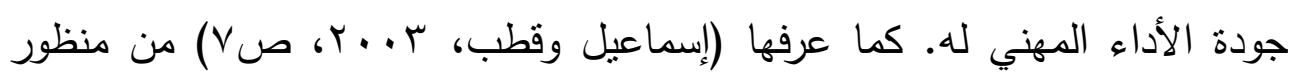
تحقيق أهداف الأطراف المرتبطة بعملية المراجع، والتي تعتمد على تقرير المراجع للوصول إلى أقصى استفادة ممكنة للأطراف المهتمة بخدمات المراجعة".

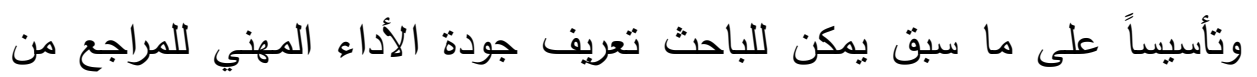

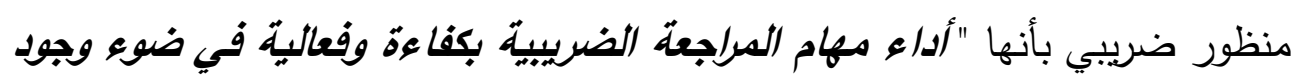

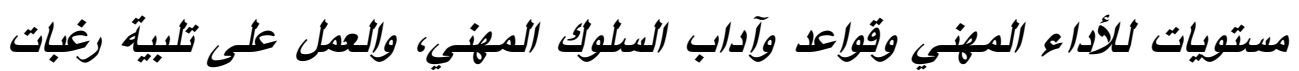

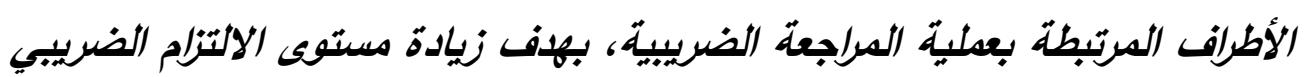


للدى العديل، بها يؤلي إلى إضفاء الثقة والدصد/قية على بيانات الإقلرا الضريبي

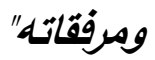

r/ مقومات الإطار المقترح للمراجعة الضرييية 1/ 1/ استقلال المراجع الضريبي:

يواجه مراجع الحسابات العديد من الضغوط والمخاوف عند ممارسته لادائه المهني، حيث يصعب أن يتحرر بصورة كاملة من كافة القيود التي قد تمارسها إدارات

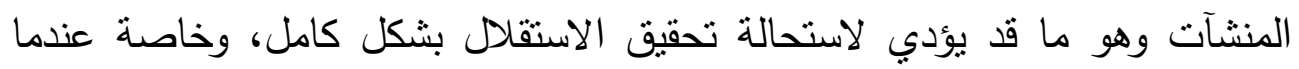

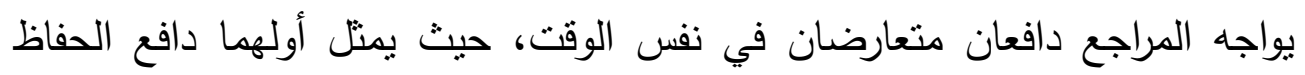

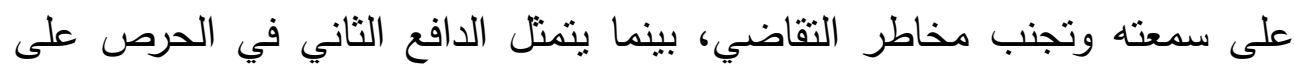

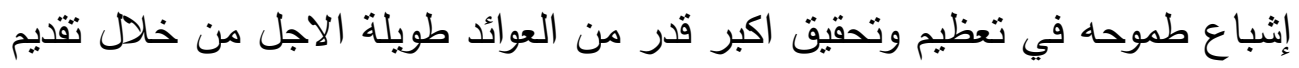

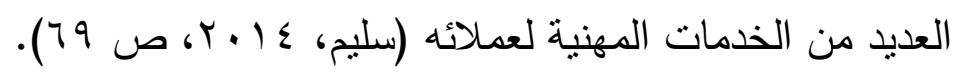

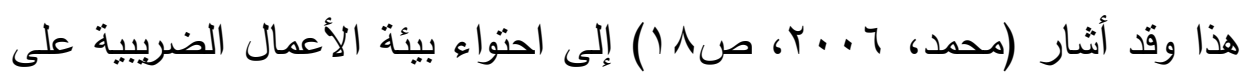
مجموعة من المصالح المتعارضة والتي تمنل ضنغوطا على المراجع قد تؤثر عليه

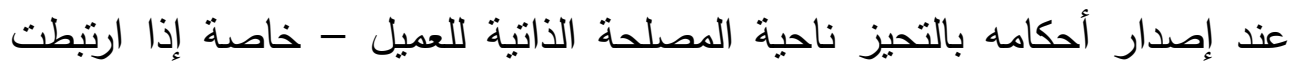

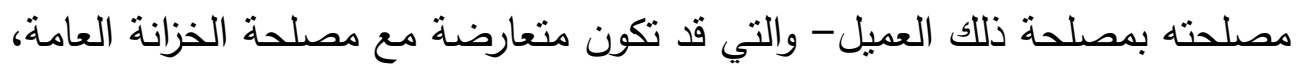

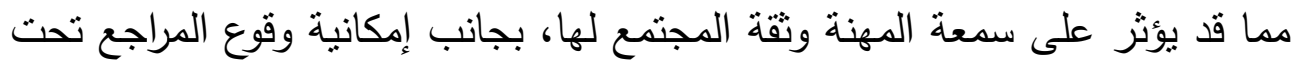
طائلة المسئوليات والعقوبات، ولتلافي ذلك يلزم ضرورة تحقيق الاستقلال المهني

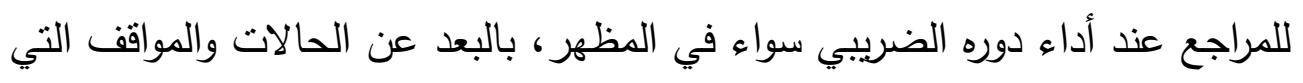

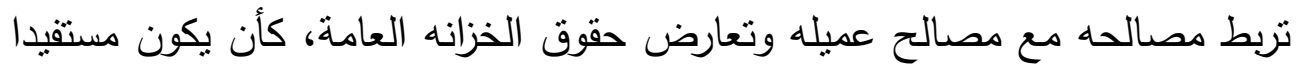

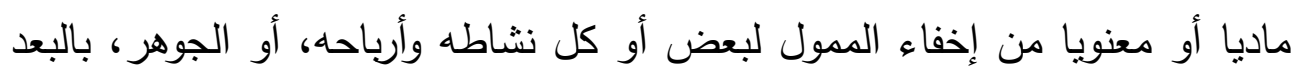
عن كل ما يؤثر على تفكيره الموضوعي مع التزامه بالحياد والتحلي بالأمانه والنزاهه

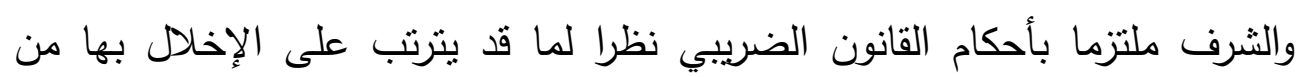

مسئوليات وعقوبات قد تؤدي به للسجن والغرامات وفقد تراخيص مزاولة المهنة.

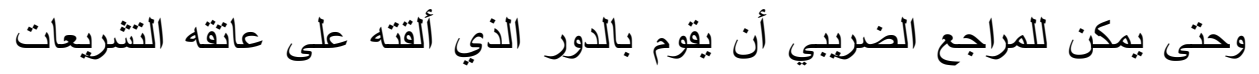

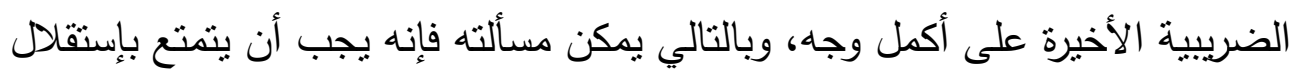
كامل، بحيث لا يخضع لأي مؤثرات تؤئر عليه عند مراجعة واعتماد الاقرارات 
الضريبية، حيث أنه إذا لم يحتفظ بإستقلال والحياد التام في كل المواقف التي تواجهه

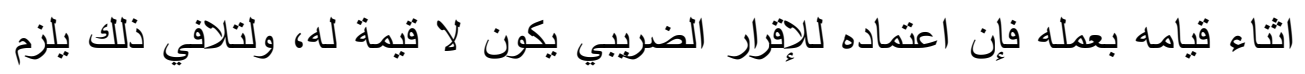

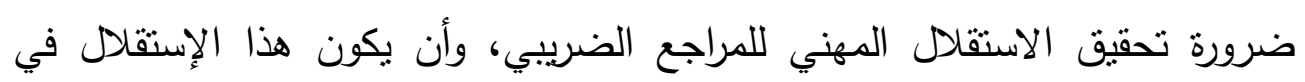

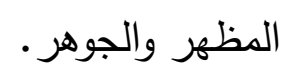
ولتحقيق الاستقلال والحياد للمراجع الضريبي يقترح الباحث ما يلي:

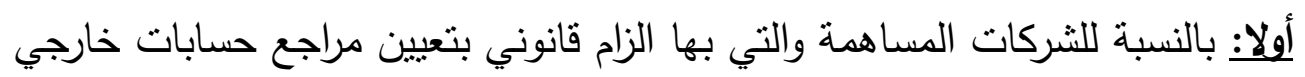

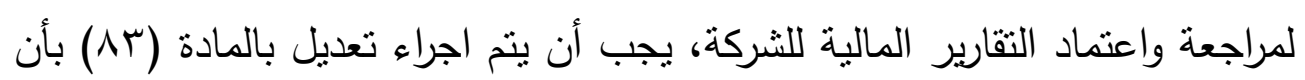

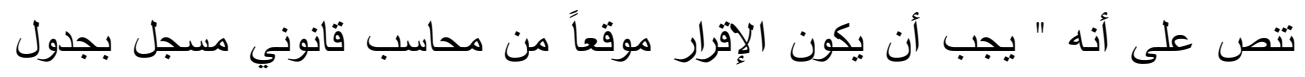
المحاسبين والمراجعين ومستقلاً عن المراجع الخارجي وذلك بالنسبة لشركات الأموال

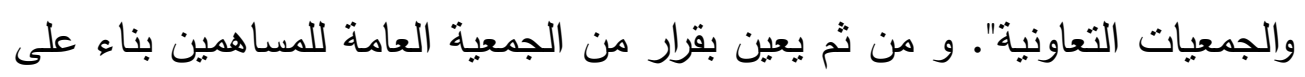

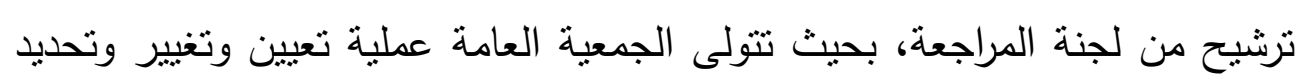
اتعابه لضمان حياده واستقلاليته.

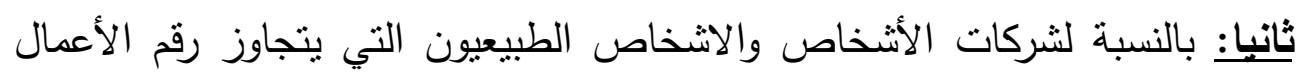

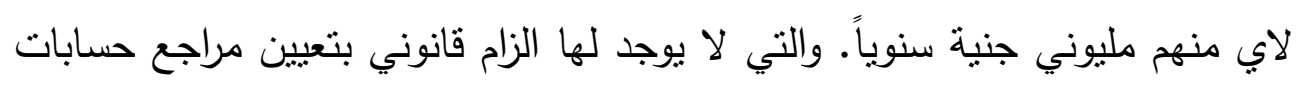

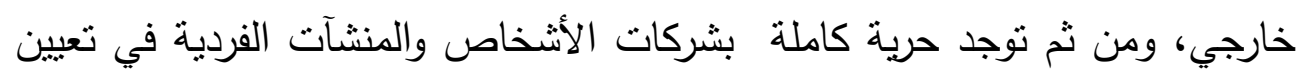

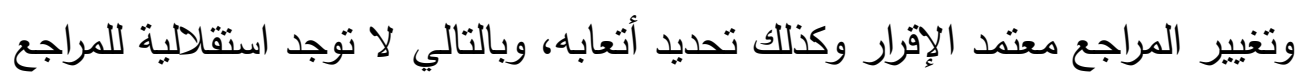

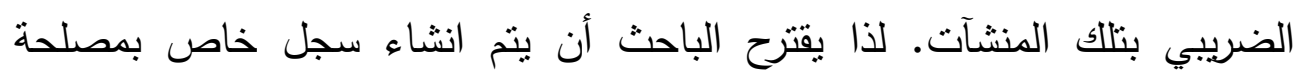

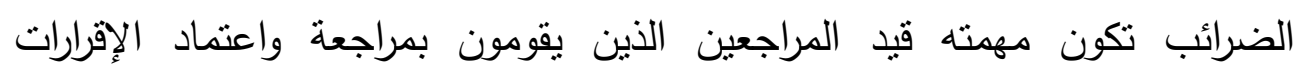

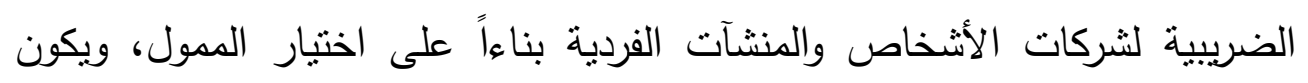

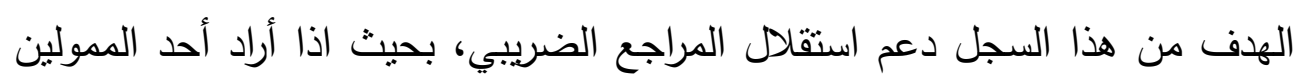

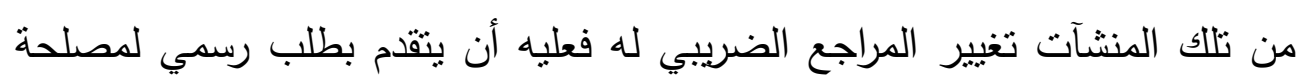

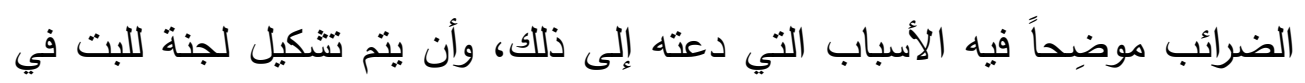

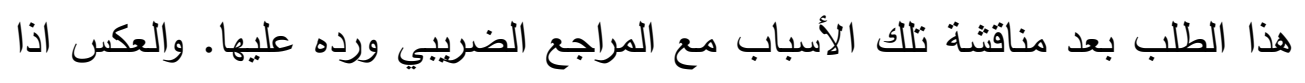

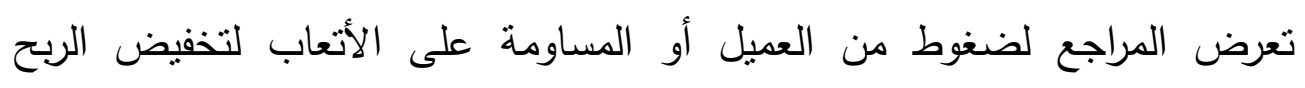

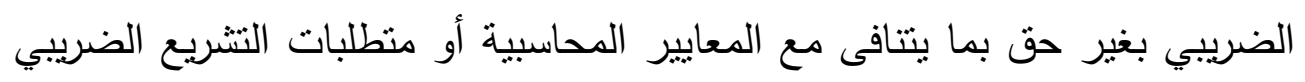
يمكنه التقام بطلب للتتحي عن هذا العميل (الممول). 


\section{تصن/ الخبرة والتأهيل المهني للمراجع الضريبي}

تعتبر الخبرة والتأهيل والمعرفة المهنية من الجوانب الهامة التي يتأثر بها الأداء

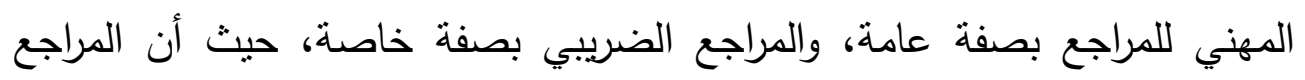

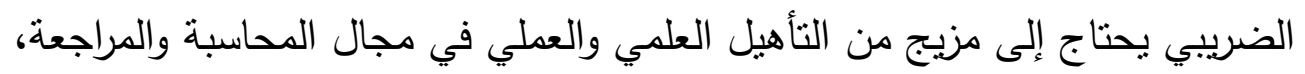

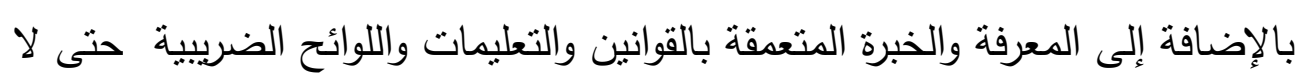

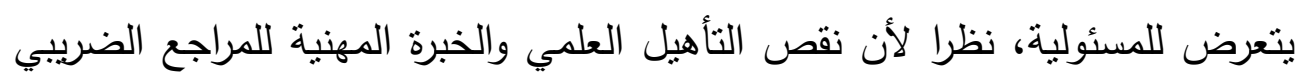

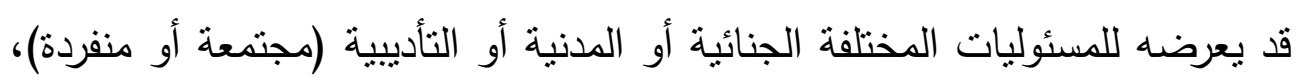

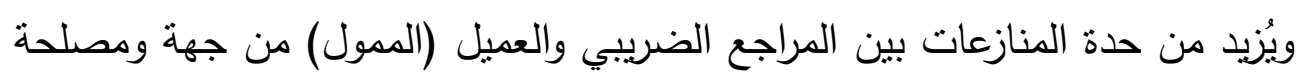

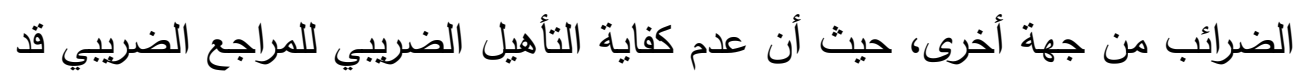

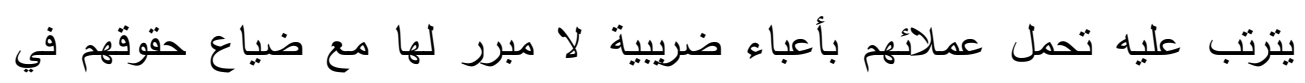

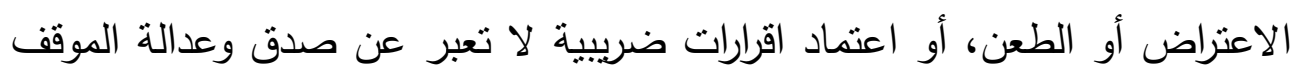

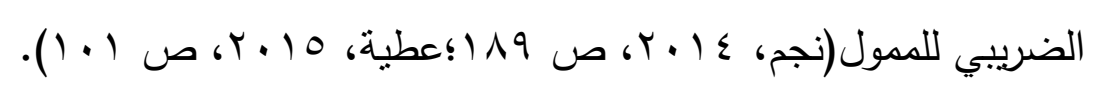

ومن ثم يرى الباحث ضرورة النظر في نظام التأهيل والخبرة المهنية للمراجع

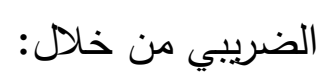

- التحديث المستمر في المقررات والمراجع الجامعية الضريبية مع تتاولها

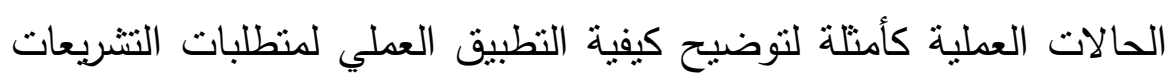

$$
\text { الضريبية. }
$$

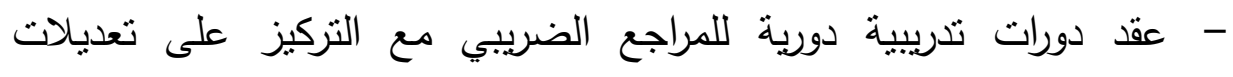

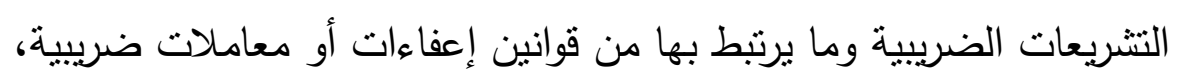

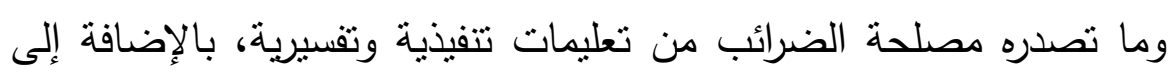

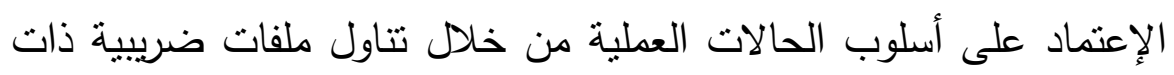

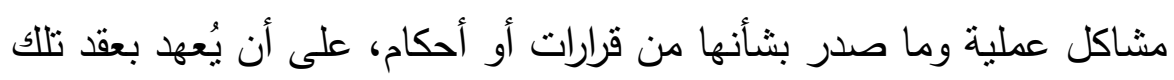

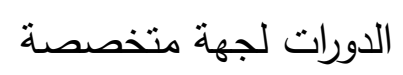
- عقد اختبارات جادة في نهاية البرامج التدريبية، على أن يكون النجاح فيها شرطا للحصول على ترخيص بمزاولة مهام المراجعة الضريبية لمدة معينة 
وليست مطلقة، على أن يتم تجديد الترخيص بعقد دورات تدريبية أخرى

$$
\text { واجنيازها. }
$$

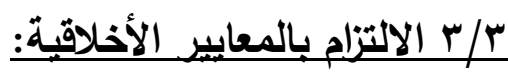

يعد التزام المراجع بالمعايير الأخلاقية من العوامل الهامة المؤثرة في جودة الأداء

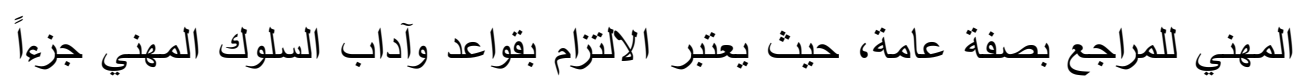

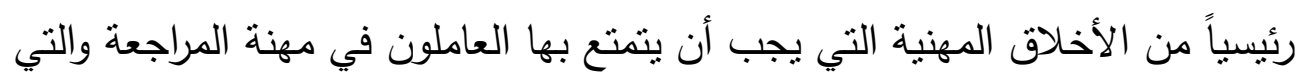
تعتبر حجر الأساس لنجاح مهنة المراجعة في أداء الدور المنوط بها، ولكي ينم النقة لئن

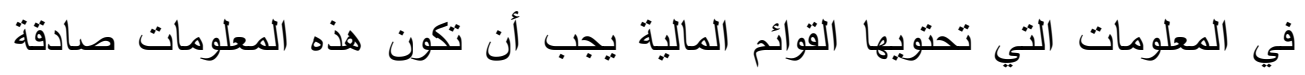

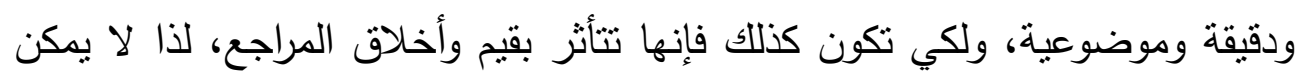

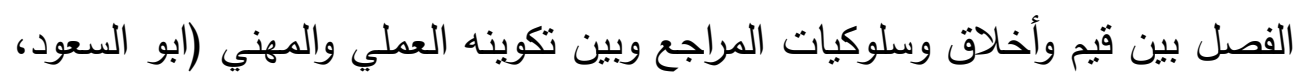

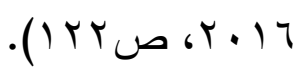

إيماناً بالقيم الإخلاقية والسلوكية التي يجب أن يلتزم بها المبان المراحعون فقد قام الاتحاد الدولي للمحاسبين (IFAC) بإصدار دليل يتضمن القواعد الأخلاقية لمهنة المحاسبة

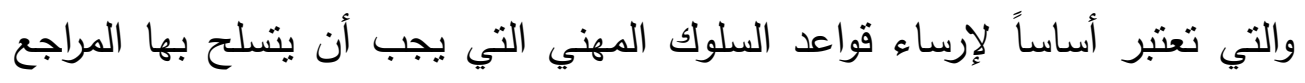

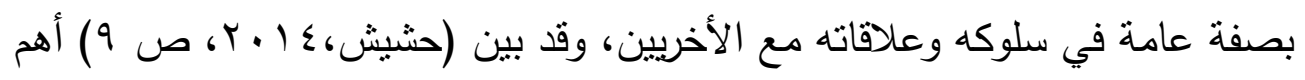

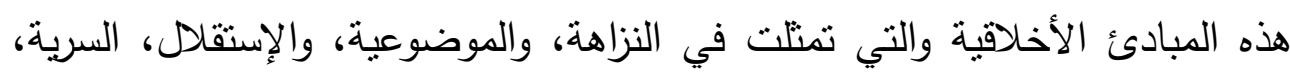
العناية المهنية، أخلاقيات المهنة.

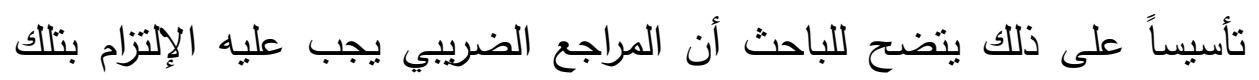

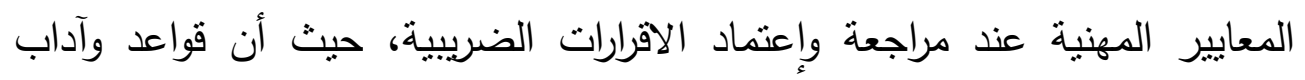

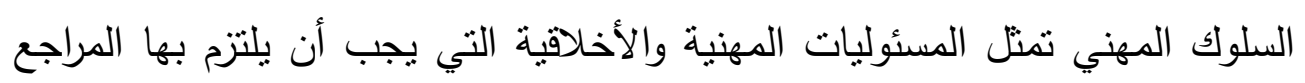

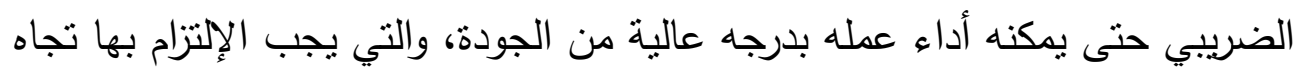
الأطراف ذات العلاقة بأن يتحرى الصدق مع نفسه، وفي إعداد وإعتماد الاقرارات

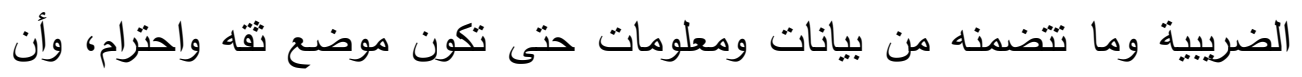

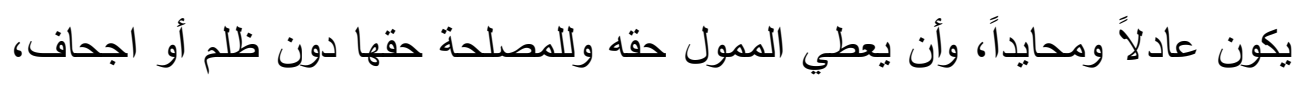

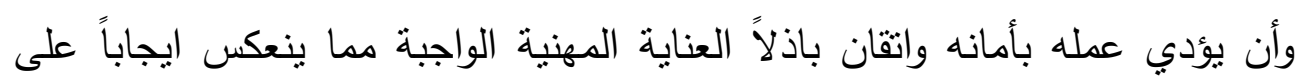


جودة الاداء المهني للمراجع الضريبي. وحتى يمكن تحقيق ذلك يقترح الباحث ما يلي:

- قيام الجمعيات المهنية بدور الفاعل في تطوير ميثاق آداب وسلوكيات المهنة

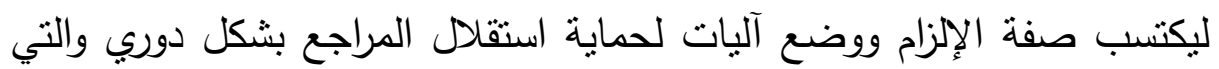

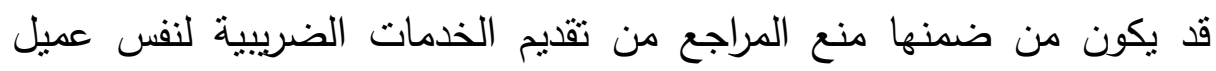
المراجعة لضمان الحياد والاستقلالية. - تدعيم مفهوم المسئولية الإجتماعية في مكاتب المراجعة وبيان أهمية الدور الدهانه

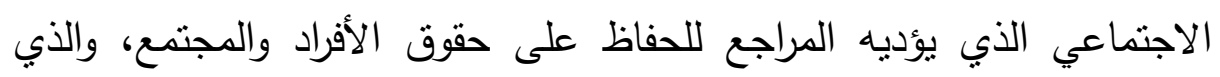

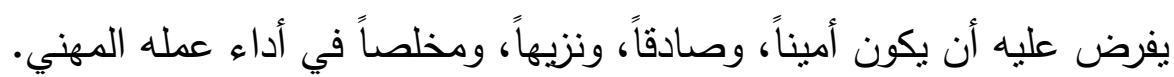
r/ץ وجود مستويات للأداء المهني لأغراض المراجعة الضريبية:

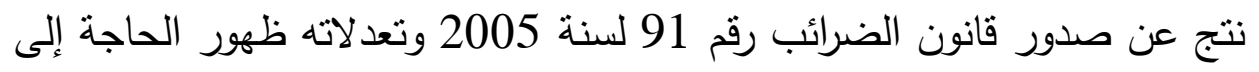
ضرورة وجود معايير أو مسنويات أداء مهنية للمراجعة الضريبية بهدف استخدامها

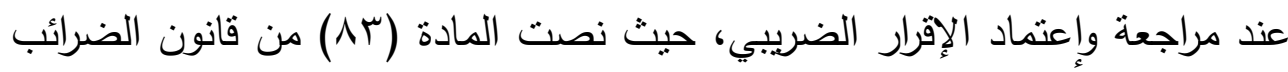
رقم ا9 لسنة ه . . r على "ضرورة اعتماد الاقرار الضريبي السنوي لكل من شركات

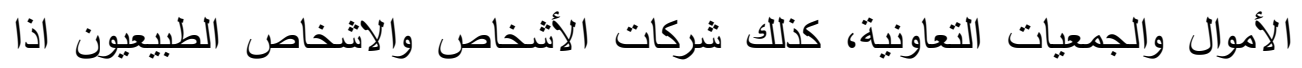

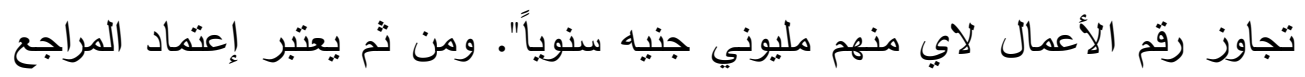

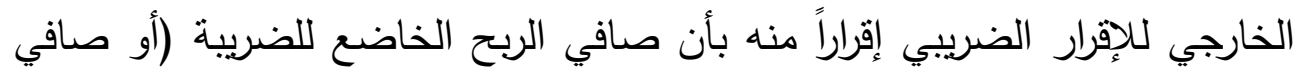

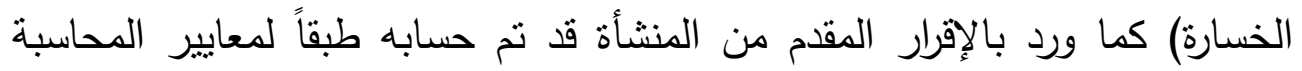
المصرية، والمبادئ المحاسبية المتعارف عليها ومتفقاً مع تطبيق أحكام قانون الضرائب على الدخل ولائحته التتفيذيه، وأصبح المحاسب القانوني ملزما بالتوقيع على التى التئي الإقرار الضريبي مع عميله وذللك تأكيداً على مسئوليته عن قيامه بجميع الفئه أعمال الفحص الضريبي وتطبيق أحكام قانون الضرائب أثناء إعداده لهذا الإقرار .

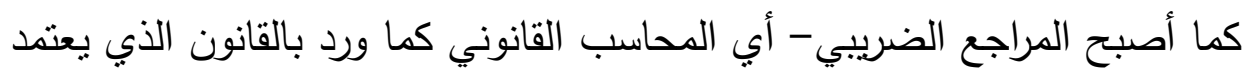

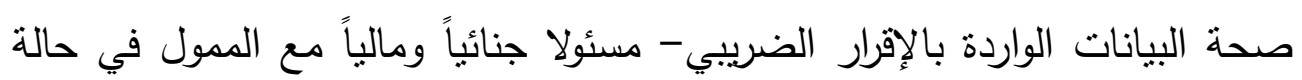

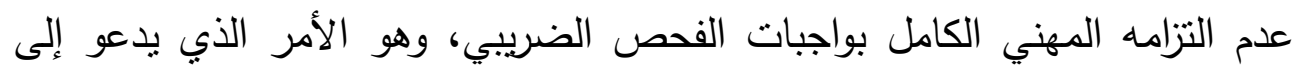

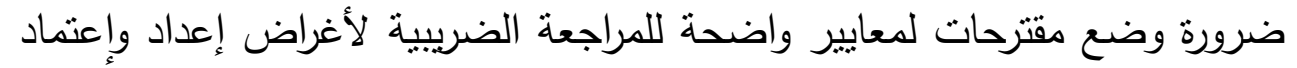


الإقرار الضريبي، بحيث توضح هذه المعايير المهام والخطوات الواجب إتباعها أثناء

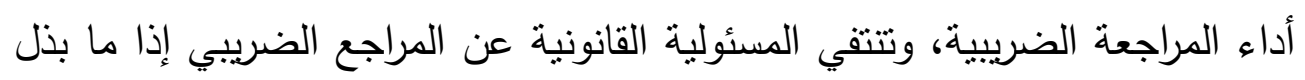
العناية المهنية الواجبة في ضوء تلاهك المعايير.

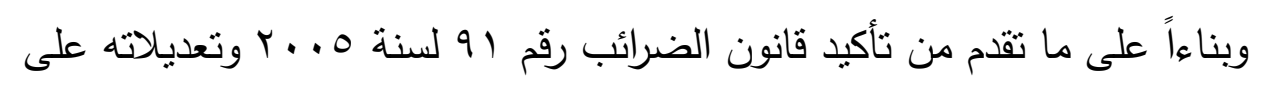

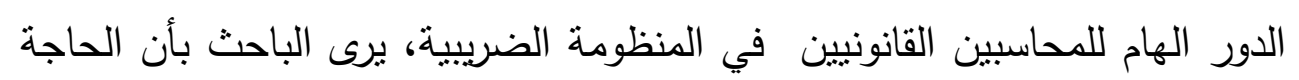

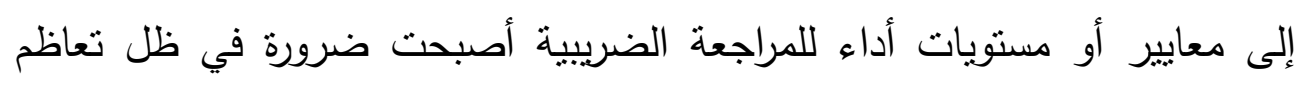

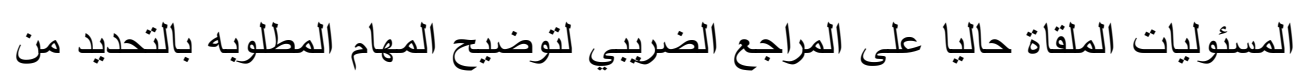

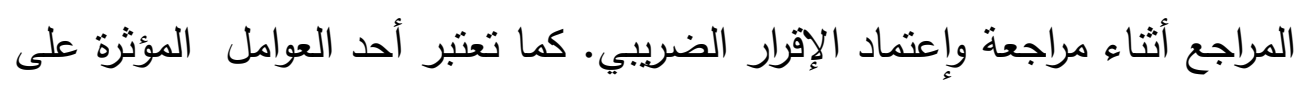

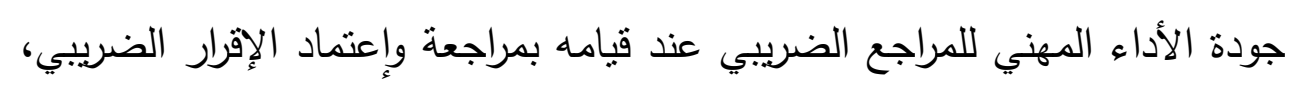

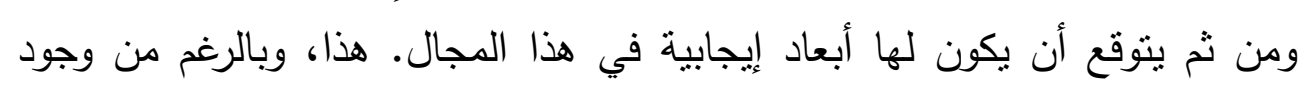

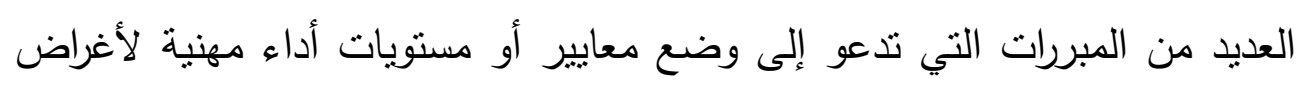

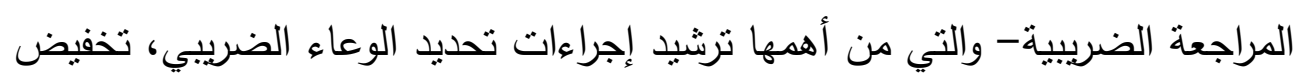

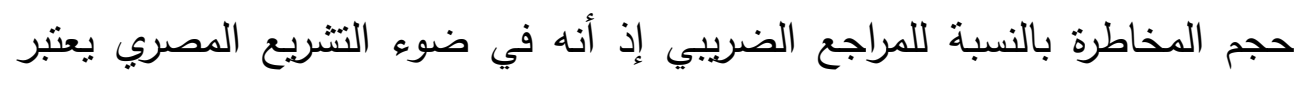

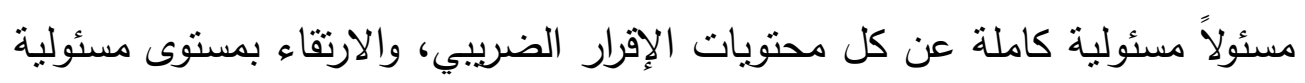

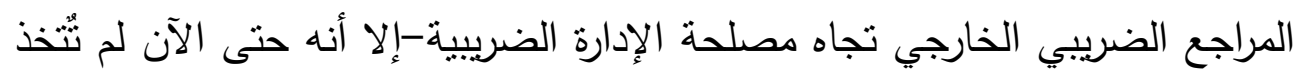

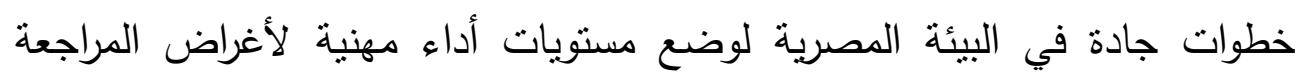

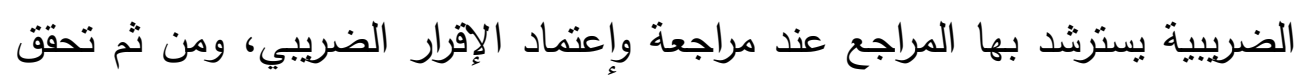
الإرتقاء بمسئولية المراجع الضريبي تجاه الإدارة الضريبية.

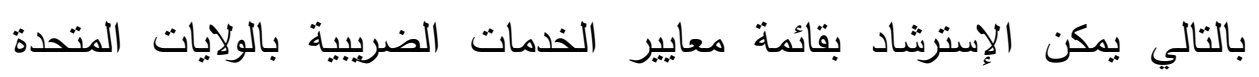
الأمريكية (SSTS) American Institute of أصدرها المعرد الأمريكي للمحاسبين القانونيين Certified Public Accountants (AICPA) سبعة معايير خاصة بالخدمات الضريبية يلتزم بها جميع المراجعين عند تقديم تلك فلك

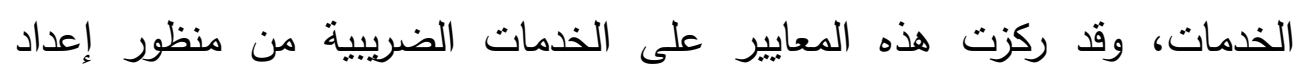

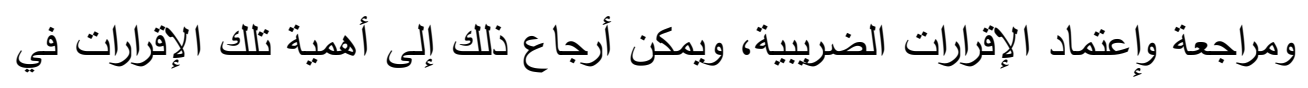

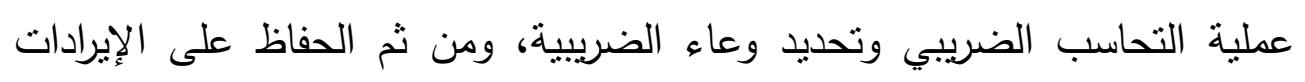


السيادية للاولة، حيث يعتبر الإقرار الضريبي وثثقة صادقة لنشاط الممول خلال الفترة

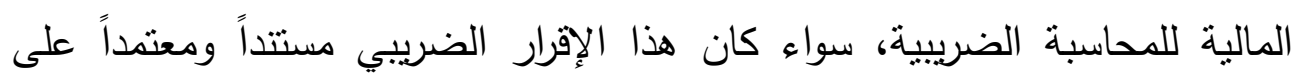
دفاتر منتظمة من عدمه.

تأسيسا على ما تقدم يرى الباحث أنه يمكن الإستفادة من تلاك المعايير وبلورتها في من مناي

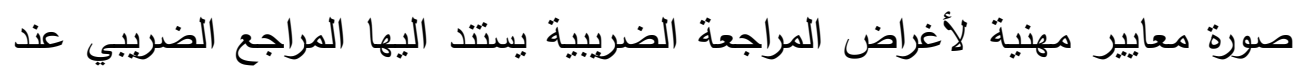

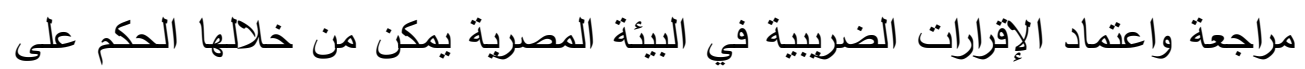

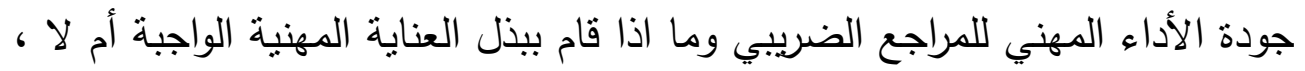
وفي ضوء تلك المعايير إذا تبين للمراجع الضريبي وجود محاولات من جانب المنشأة

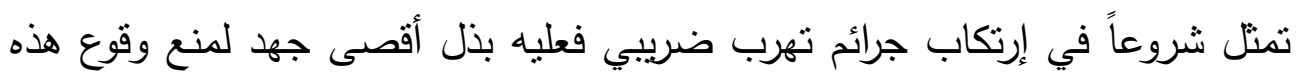

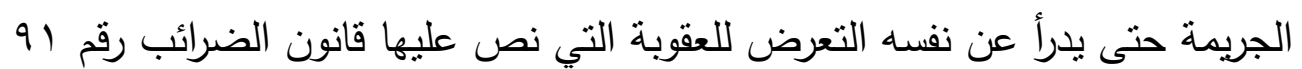

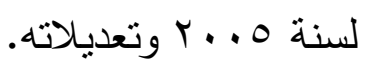

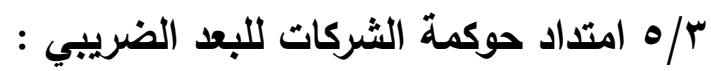

تتكل حوكمة الثركات عنصرا رئيسياً في تحسين الكفاءة الاقتصادية، وتعزيز نقة المستثمرين، حيث تتطوي على مجموعة من العلاقات بين إدارة الثركة، ومجلس

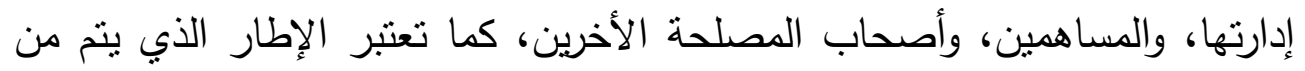

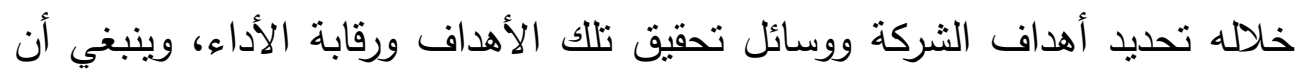
توفر حوكمة الثركات الجيدة حوافز مناسبة لمجلس الإدارة تعمل على تحقيق

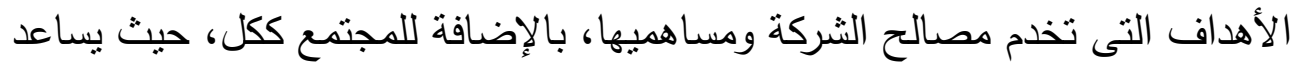
وجود نظام فعال لحوكمة الثركات داخل الثركات والاقتصاد ككل على توفير درجة الإضها من الثقة في بيئة الأعمال. بالتالي لابد من الخروج من النظرة الضيقة للحوكمة والتي يُنظر إليها على أنها

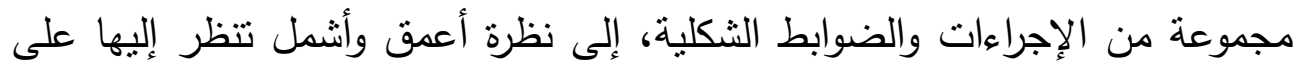

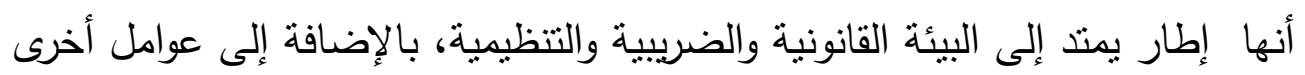

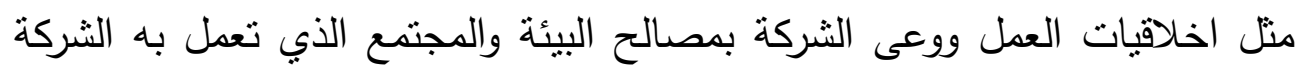

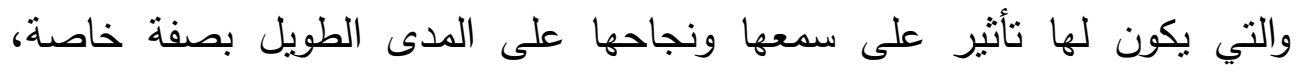
والمجتمع ككل بصفة عامة، وهذا ما بدأت يتجه إليه الفكر المحاسبي في الأونة 
الأخيرة، حيث أتجهت تلك الدراسات إلى تتاول العلاقة بين حوكمة الثركات وممارسات التخطيط الضريبي التي تتبعها الثركات، بإلاضافة إلى المسئولية

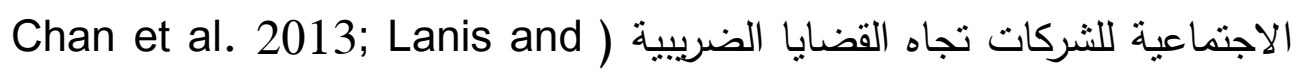
.(Richardson, 2015; Watson, 2015 إذ أن الضرائب تمثل جزءاً كبيراً من أرباح الثركات، ومن ثم تشعى الثركات إلى بـ

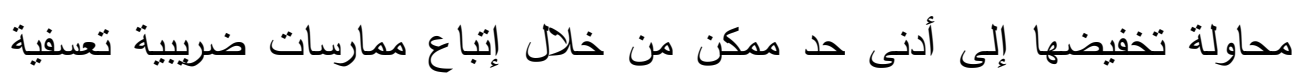

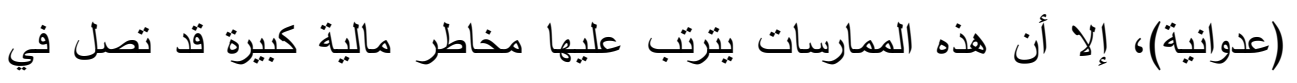
بعض الاحيان إلى إفلاس الثركة، حيث أن التعديلات الضريبية التي ستقوم بها

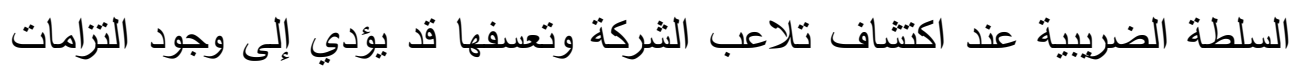
ضريبية كبيرة على الثركة قد ينتج عنها اضطراب احوالها وافلاسها. كما تتمنل مخاطر السمعة التي قد تتعرض لها الثركة عند استخدام تلاك الاستراتيجيات العدوانية

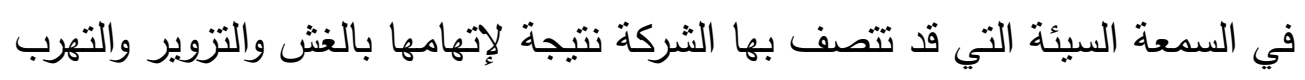
الضريبي (Friese et al., 2008)، ومن ثم لابد من المشاركة الفعالة لمجلس

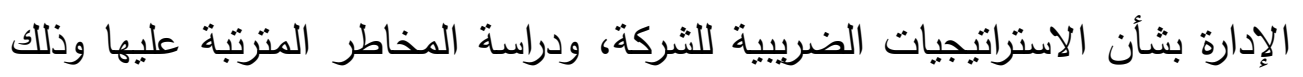

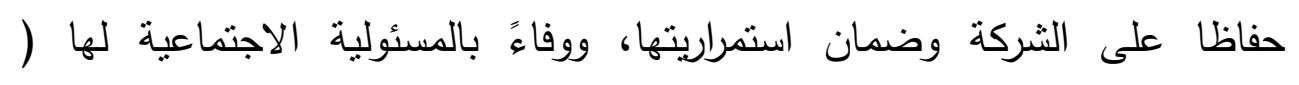
.(Hasseldine and Morris, 2013; Hartnett, 2008, p. 3 هذا وقد أنشار ( Owens, 2008, p. 9-11) إلى أن هذه الممارسات قد

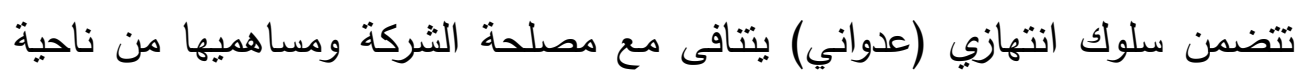

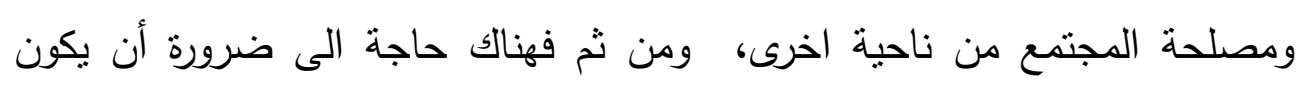

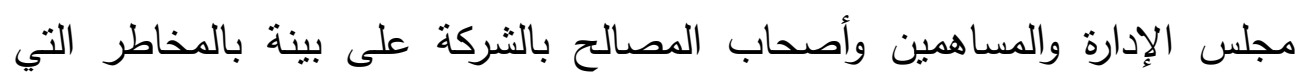

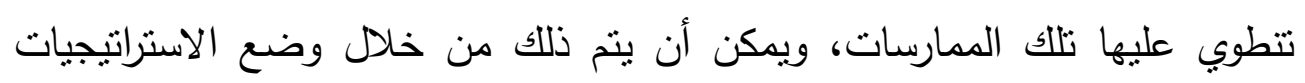

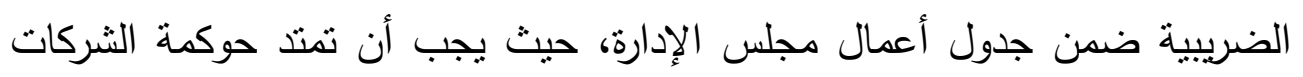

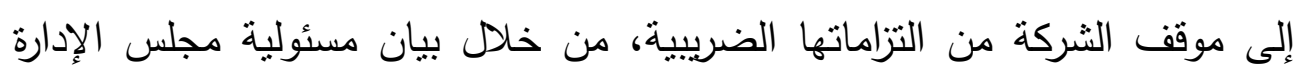

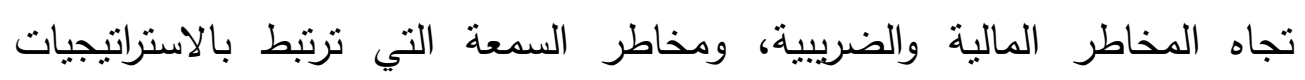
الضريبية التي تتبعها إدارة الثركة. 


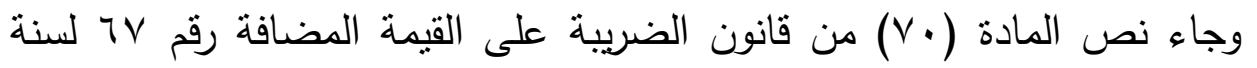

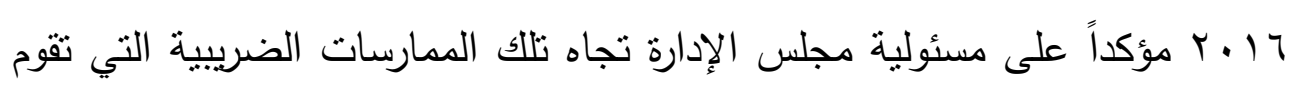
بها الثركة، حيث نصت على أنه في حالة وقوع أي فعل من أفعال التهرب من الإداه

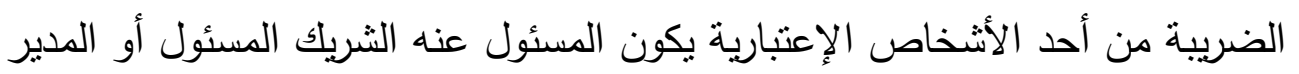

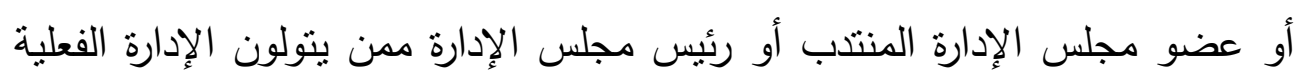

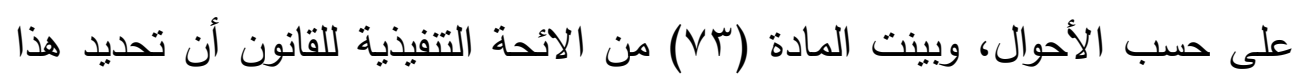

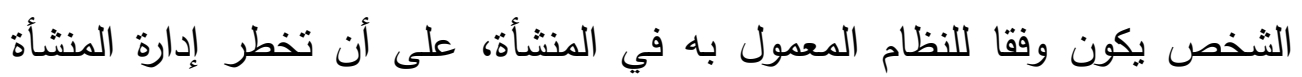
المأمورية المختصة باسم المسئول عند تغييره وذلك خلال واحد وعشرين يوماً.

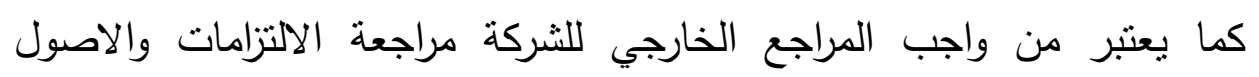
الضريبية، بالاضافة الى المخاطر الضريبية التي قد تتعرض لها الثركة الثركة نتيجة

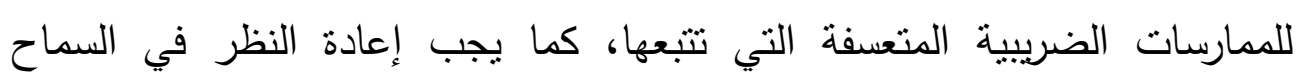

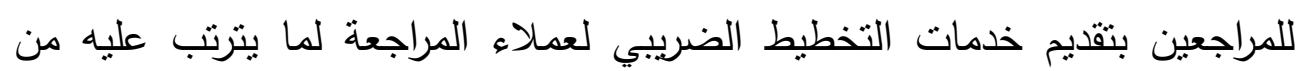
التشكيك في استقالية المراجع نتيجة لتعارض المصالح بين مهام المراجعة ومهام

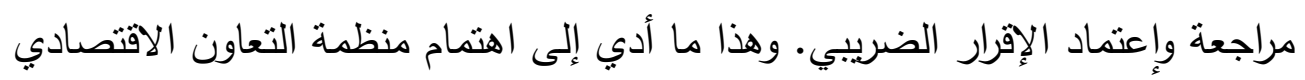

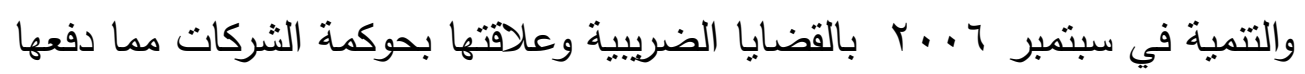
في هذا المؤتمر للإهنمام بمحورين اساسيين هما (Hartnett, 2008, p. 3):

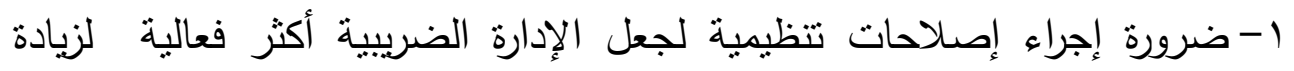

$$
\text { مستوى الالتزام الضريبي }
$$

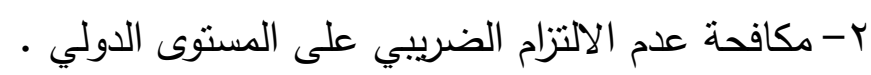

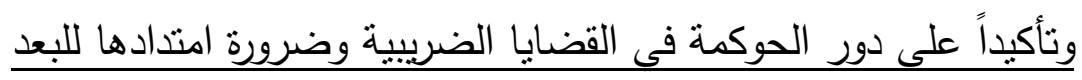

$$
\text { الضريبي تم التركيز في هذا المؤتمر على ما يلي: التئي }
$$

أ- تحسين استخدام إدارة المخاطر وامتداد نشاطها للمخاطر الضريبية.

ب-تشجيع الإدارة العليا ولجان المراجعة في الثركات الكبيرة على اتخاذ وزيادة

$$
\text { الاهتمام بالمسؤولية الثخصية عن الاستراتيجيات الضريبية. }
$$

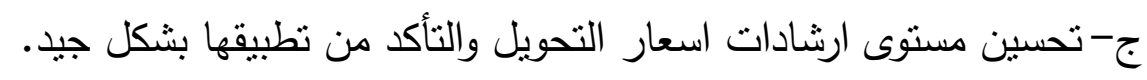




$$
\text { د- دراسة دور المراجع الضريبي الخارجي في الحد من سلوك عدم الالتزام }
$$

هـ -التوسع في ارشادات حوكمة الثركات الصادرة عن منظمة التعاون الاقتصادي

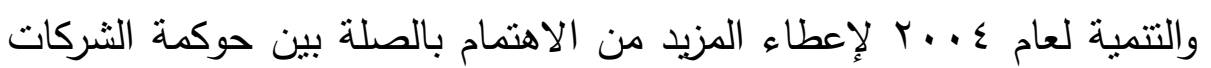

$$
\text { والاستراتيجيات الضريبية التي قد تتبعها الثركات. }
$$

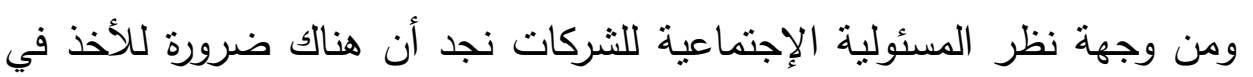

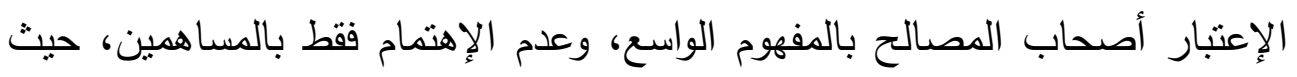

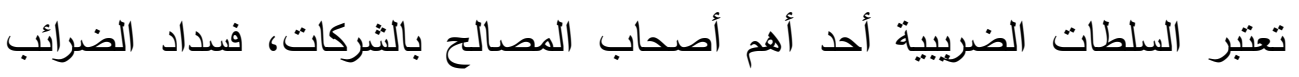
يتضمن أثنار اجتماعية على المجتمع لأن الحصيلة الضريبية للدولة تمثل عامل الهن

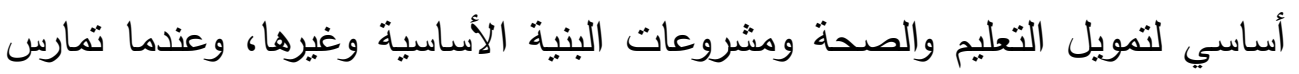

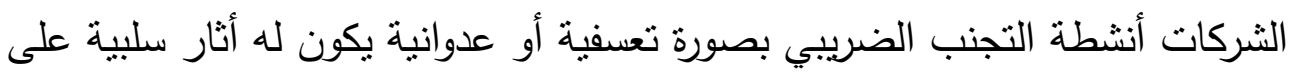

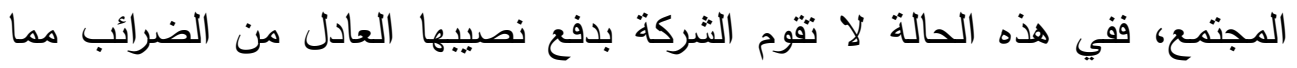
يترتب عليه خسارة كبيرة للمجتمع ككل على المدى الطويل، كما يترتب عليه ضرر

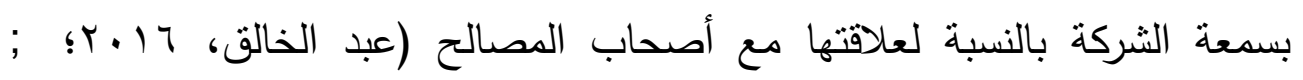
Watson, 2008 Friese et al., 2014 مفهوم الحوكمة للبعد الضريبي يعمل على خلق مناخ من الثفافية والإنضباط للحفاظ على حقوق الدولة من الإيرادات الضريبية وحماية حقوق المساهمين نتيجة لسلامة

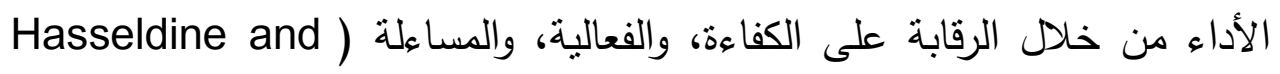
.(Morris, 2013

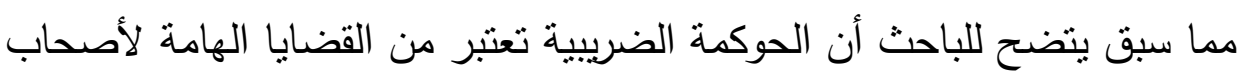

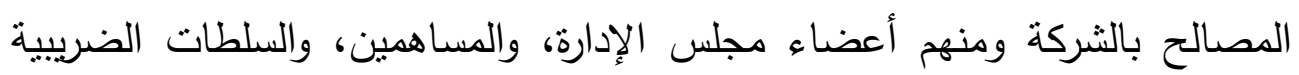

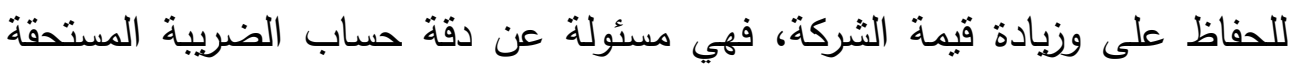
على الثركة بالإضافة إلى تجنب المخاطر الضريبية والحد من الممارسات الضريبه لصنيبة

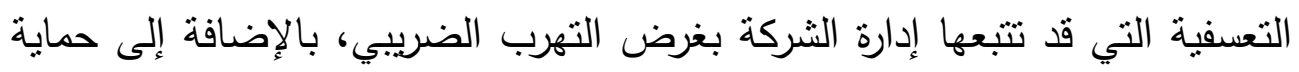

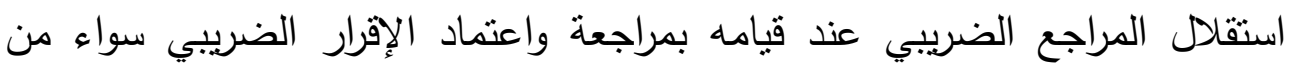

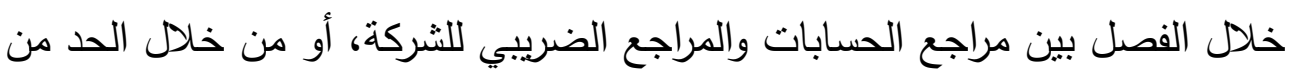


الضغوط التي قد تمارسها الإدارة عليه لتخفيض الالتزامات الضريبية للثركة بدون

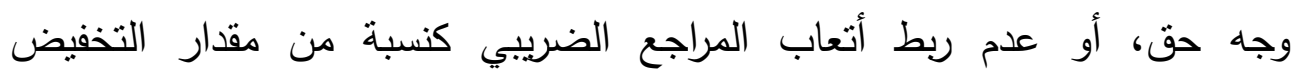

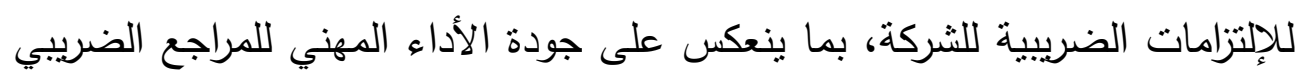

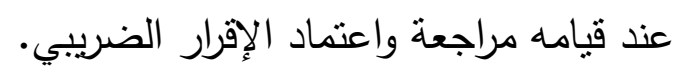
كما تعتبر الحوكمة صمام أمان للمراجع الضريبي وعامل رئيسي في أداء الأه عمله

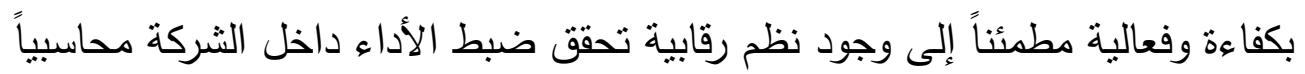

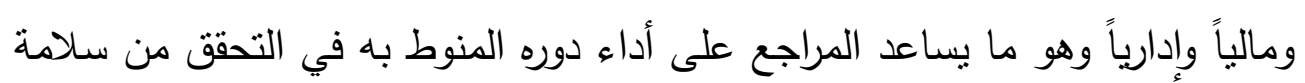

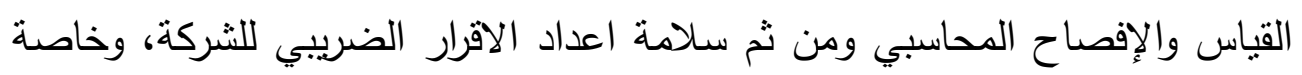
إذا ما أمتدت إلى البعد الضريبي ومسئوليات مجلس الإدارة تجاه الممارسات الضريبية التي تقوم بها الثركة والمخاطر التي قد تترتب عليها. ء / انعكاس الإطار المقترح للمراجعة الضريبية الخارجية على جودة التقارير المالية

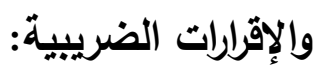

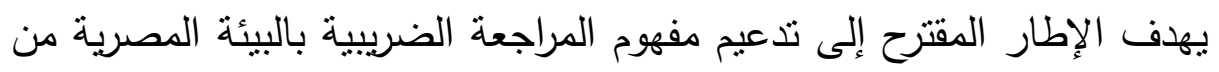

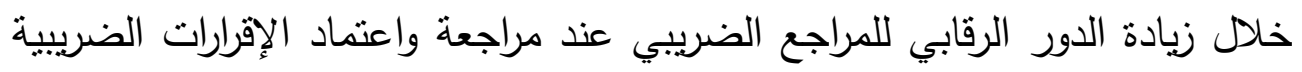

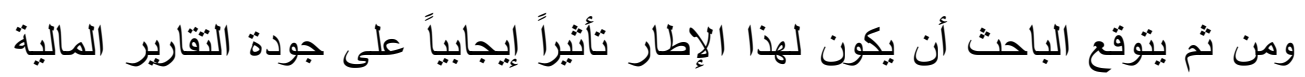
والإقرارات الضريبية، ويمكن توضيح ذلإنك كما يلي:

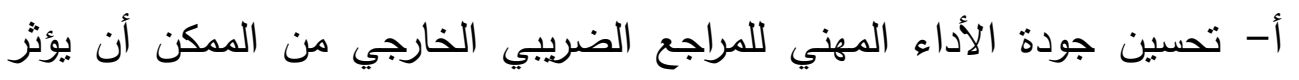

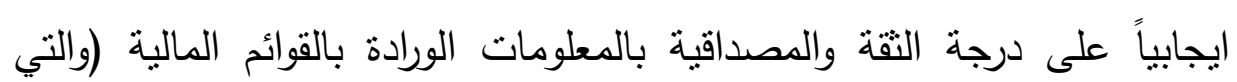

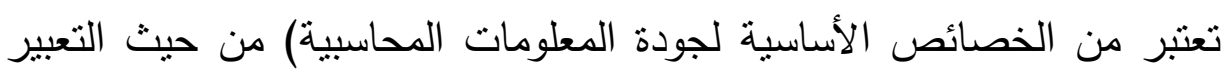

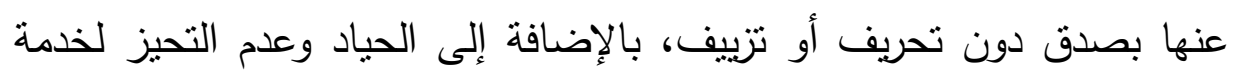

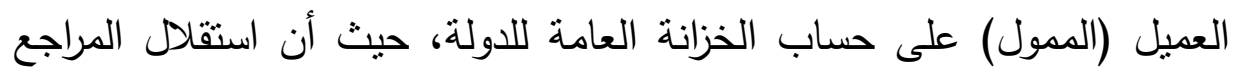

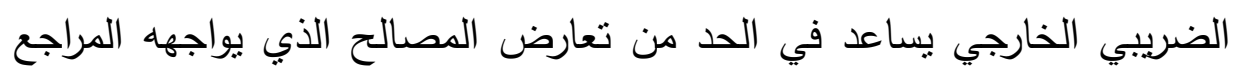

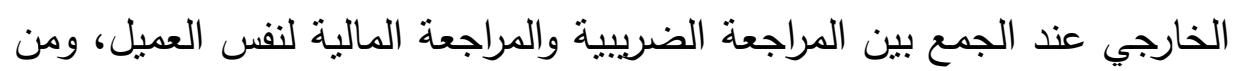

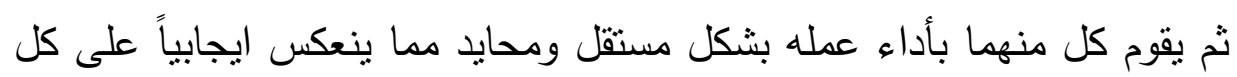
من جودة التقارير المالية والإقرارات الضريبية. 
ب-قيام المراجع الضريبي بدور رقابي على جودة مراجعة القوائم المالية من خلال

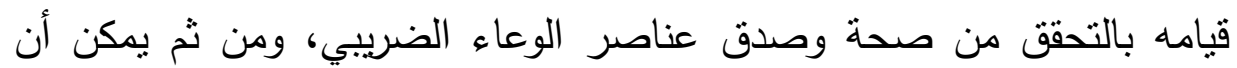

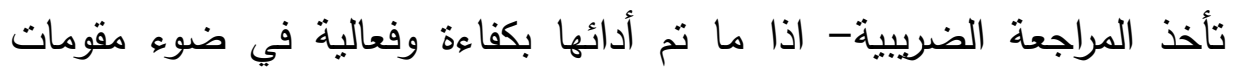

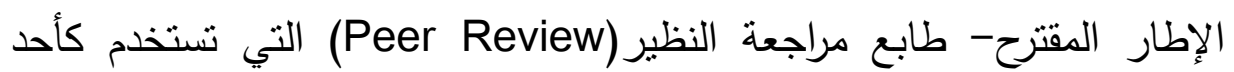

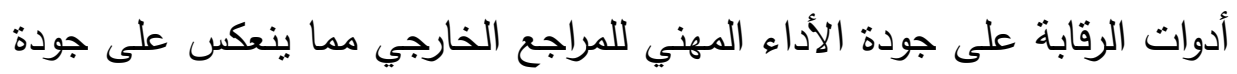

$$
\text { التقارر المالية والإقرارات الضريبية. }
$$

ج-وجود مراجع ضريبي مستقل لمراجعة واعتماد الإقرار الضريبي ينعكس إيجابياً

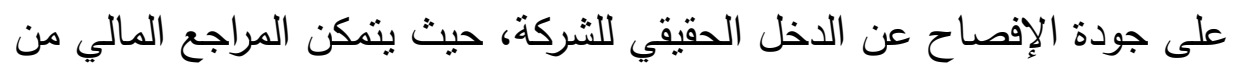

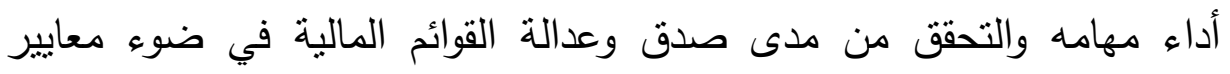

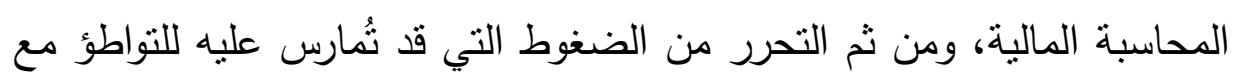

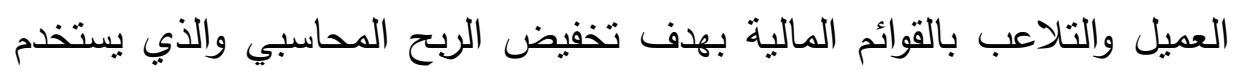

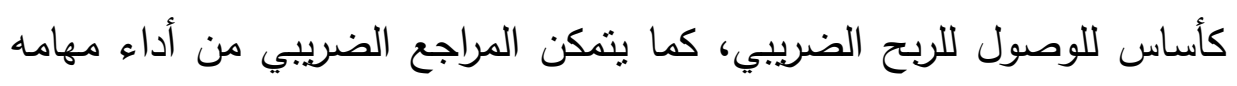

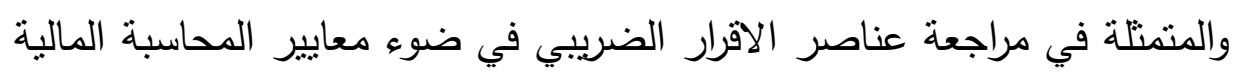

$$
\text { ومتطلبات التشريع الضريبي. }
$$

د- وجود مراجع ضريبي خارجي مستقل لايه التأهيل والخبرة الضريبية الكافية يساعد في اكتثاف والحد من التلاعب في القوائم المالية من أجل إخفاء الربح الحقيقي

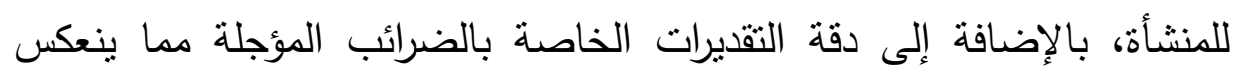
ايجابياً على جودة التقارير المالية والإقرارات الضريبية.

الخلاصة والنتائج:

تتاول الباحث في هذا البحث دور المراجع في ظل التشريعات الضريبية

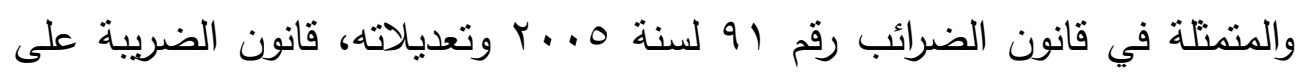

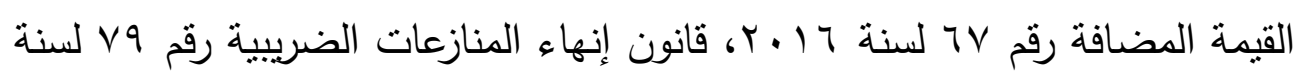

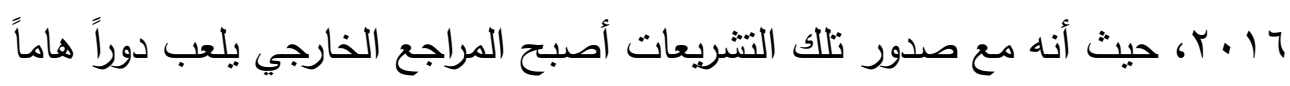

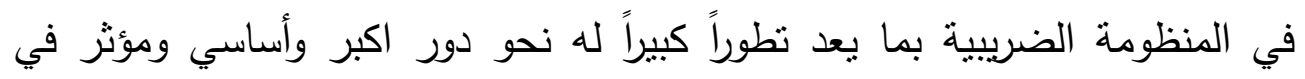

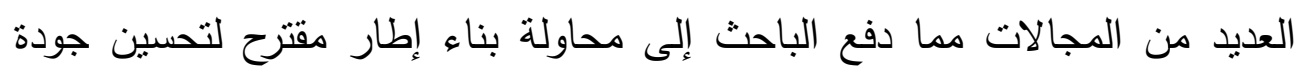
الأداء المهني للمراجع الضريبي مع بيان انعكاس ذللك على جودة التقارير المالية 
والإقرارات الضريبية من خلا التحقق من صحة وصدق البيانات المدرجة بالإقرار

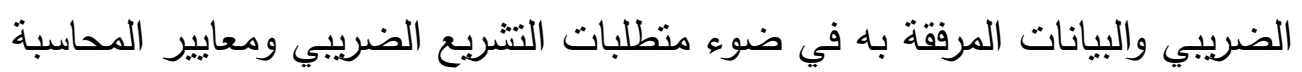

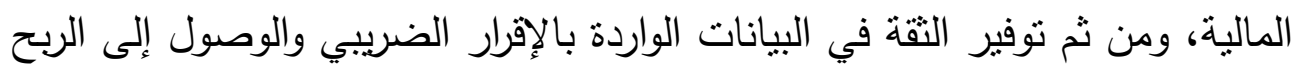
الخاضع للضريبية، وحماية موارد الدولة. ويساهم الإطار المقترح للمراجعة الضريبية الخارجية إلى تدعيم الدور الرقابي لإنه

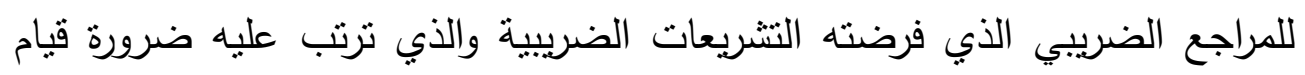

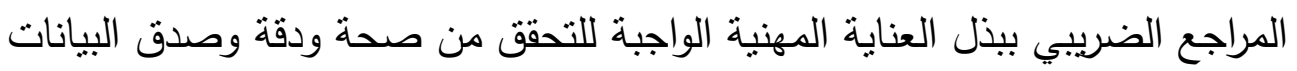
المدرجة بالإقرار الضريبي ومرفقاته في ضوء منطلبات التشريع الضريبي ومعايير

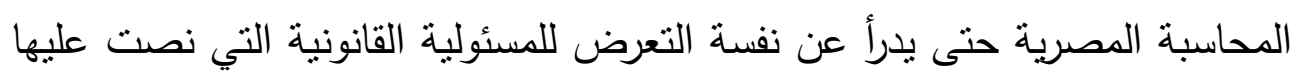

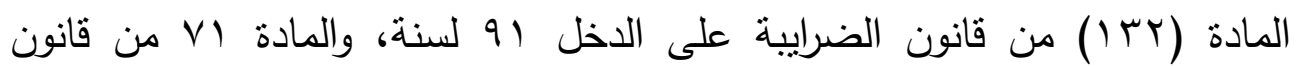

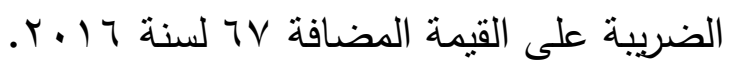
توصل الباحث من خلال الدراسة العملية إلى وجود علاقة ايجابية ذات دلالة احصائية بين مقومات الإطار المقترح للمراجعة الضريبية (الاستقلال، التأهيل والخبرة الضرييية، الالتزام بالمعايير الاخلاقية، وجود معايير لأغراض المراجعة

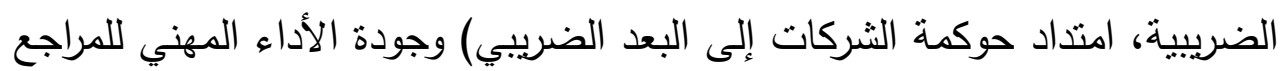

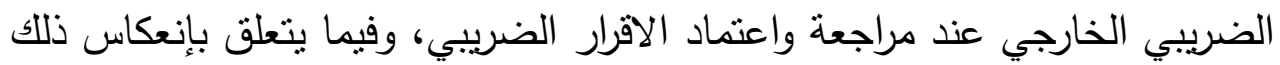

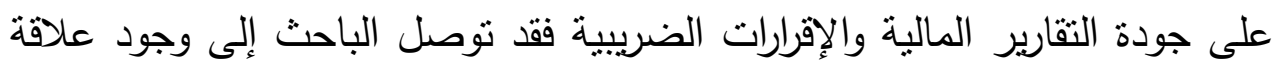

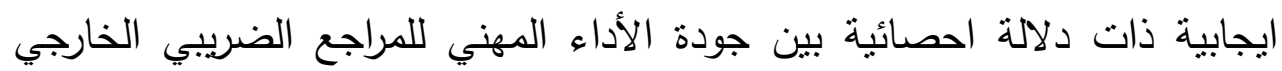
وجودة التقارير المالية والإقرارات الضريبية". 


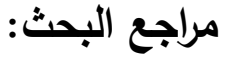

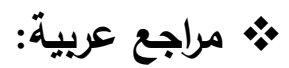

ابو السعود، عادل على حسن، 17 أب، نموذج مقترح لقياس تأثثر تطبيق حوكمة الثركات في تفعيل جودة اداء واستقلال المراجعين، رسالة دكتوراة، كلية التجارة، جامعة عين شمس.

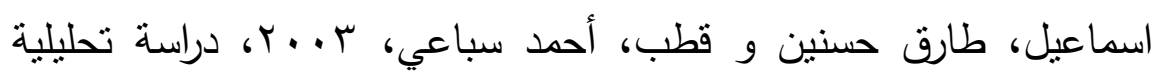

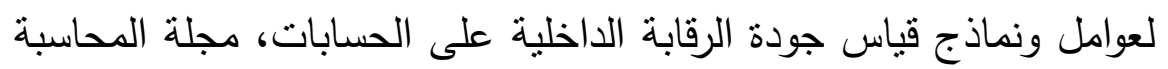

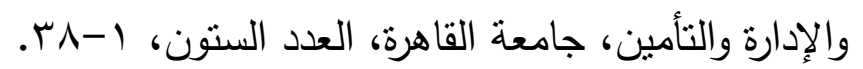

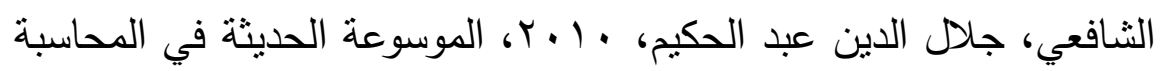
الضريبية، الجزء السادس، دراسات متقدمة في المحاسبة الضريبية، الطبعة

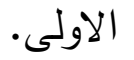

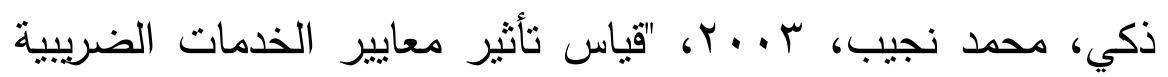
للأداء المهني للمحاسب القانوني على جودة تحديد الوعاء الضريبي: دراسة نظرية ميدانية"، المجلة المصرية للدراسات التجارية، كلية التجارة، جامعة المنصورة، العدد الأول.

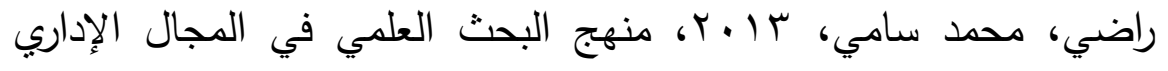

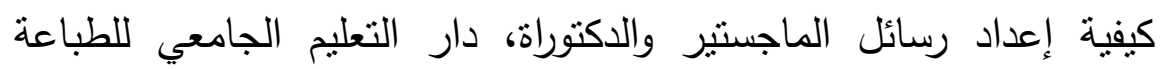
والنشر والتوزيع، الإسكندرية.

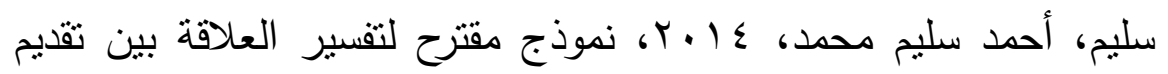
الخدمات بخلاف المراجعة وجودة مراجعة القوائم المالية: دراسة ميدانية، رسالة دكتوراه، كلية التجارة، جامعة عين شمس.

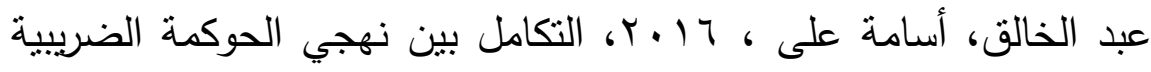

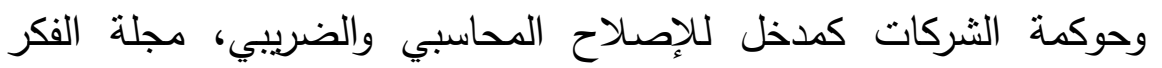

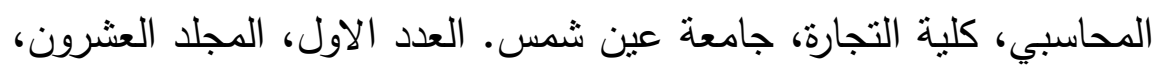

$$
\text { . VAT - T } \leqslant 9
$$




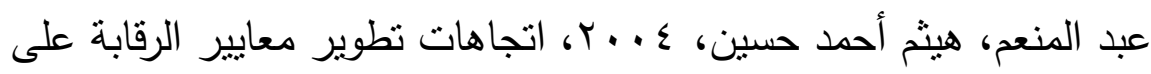

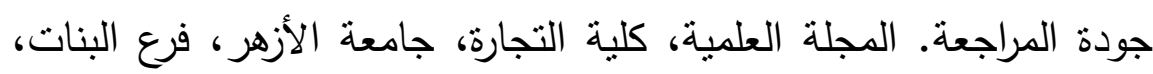

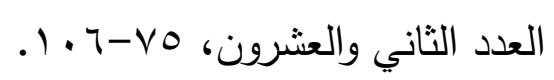

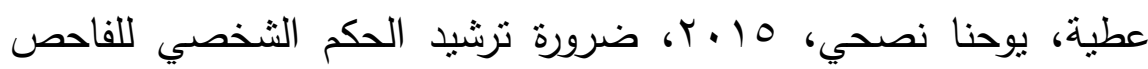

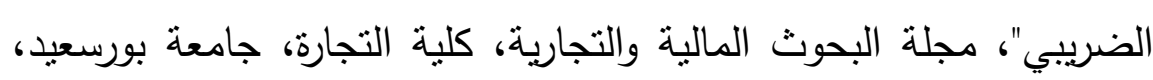

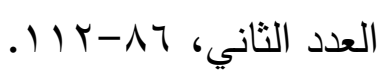

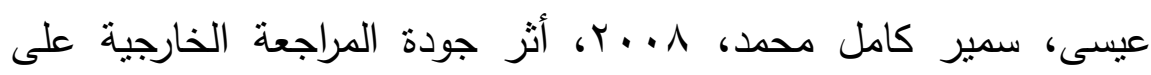

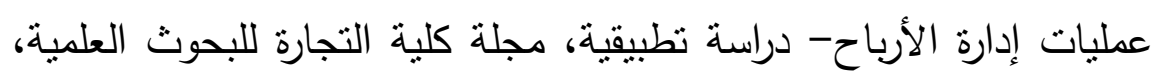

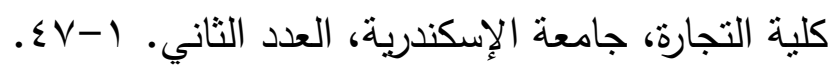

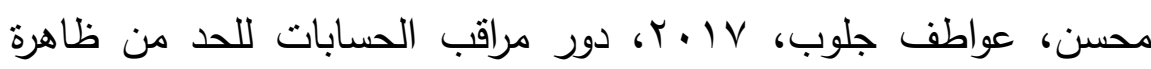

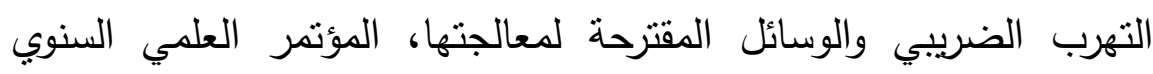

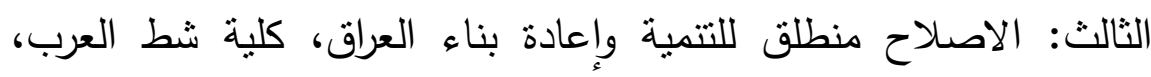

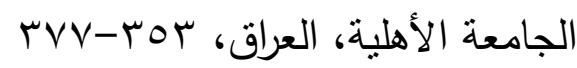

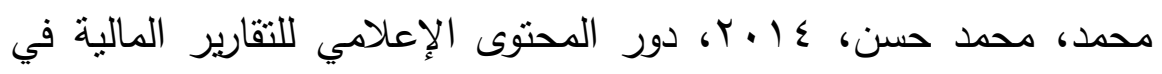

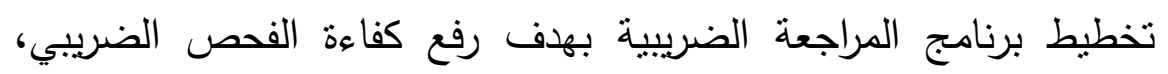

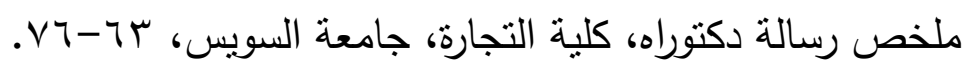

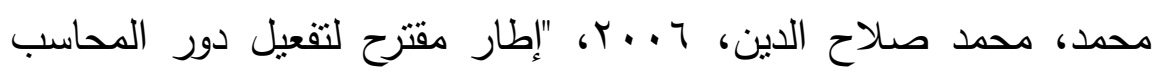

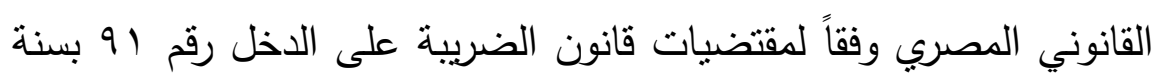

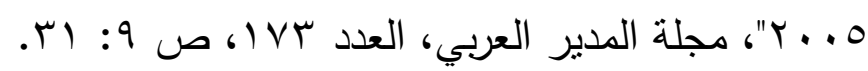

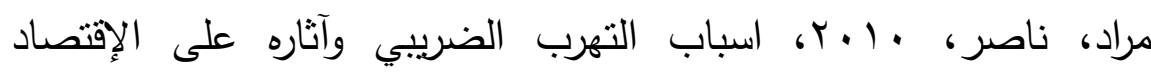

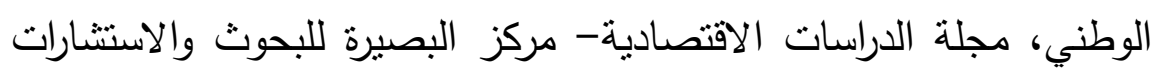

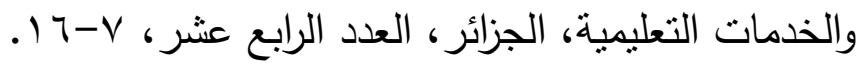
•

- Abdoil, M. R, 2010, Independence and Impartiality of Auditors from the viewpoints of Independent Auditors and 
Investment Companies, European Journal of Social Sciences. Vol. 15, No.2, pp. 281.

- Chan, H., P. Mo and A. Zhou, 2013, Governance Ownership, Corporate Governance and Tax Aggressiveness: evidence from china, Accounting and Finance, Vol. 53, pp. 1029 - 1051 .

- Christensen, B. E., A. J. Olson, T. C. Omer, 2015, The Role of Audit Firm Expertise and Knowledge Spillover in Mitigating Earnings Management through the Tax Accounts

- DeZoort, F. Todd, Paul D. Harrison, and Edward J. Schnee, 2012, Tax Professionals' Responsibility for Fraud Detection: The Effects of Engagement Type and Audit Status, Accounting Horizons, Vol.26, No.2, pp. 289-306.

- Friese, A., S. Link, and S. Mayer, 2008, Taxation and Corporate governance- The State of the art, Tax and Corporate governance, pp. 357-425.

- Hartnett, Dave. 2008. The Link Between Taxation and Corporate Governance. Tax and Corporate Governance (Edit Book). 3: 3-357.

- Hasseldine, J., and Morris, G., 2013, Corporate Social Responsibility and Tax Avoidance: A Comment and Reflection, Accounting Forum, Vol. 37, No.1, pp. 1-14.

- Hanlon, M., J. Hoopes, N. Shroff, 2012, The Effect of Tax Authority Monitoring and Enforcement on Financial 
Reporting Quality. the Journal of the American Taxation Association, Vol. 36, No.2

- Lanis, R., G. Richardson, 2015, Is Corporate Social Responsibility Performance Associated with Tax Avoidance?, Journal of Business Ethics, Vol. 127, pp. 439-457.

- Leng, M. O., 2012, Increased focus on tax governance, International Tax Review, London, Available online at:

- McGuire, S.T., Omer, T.C. and Wang, D. (2012), "Tax avoidance: does tax-specific industry expertise make a difference?", The Accounting Review, Vol. 87, No. 3, pp. 975-1003.

- Owens, Jeffrey p. 2008. Good Corporate Governance: The Tax Dimension. Tax and Corporate Governance (Edit Book), pp. 3-357.

- Watson, L., 2015, Corporate Social Responsibility, tax avoidance, and earnings performance, Journal of the American Taxation Association, Vol. 2, No.3, pp.51-64. 